\title{
Public Green Infrastructure Contributes to City Livability: A Systematic Quantitative Review
}

\author{
Jackie Parker ${ }^{1}$ and Greg D. Simpson ${ }^{2, *(D)}$ \\ 1 School of Design and Built Environment, Curtin University, Perth WA 6102, Australia; \\ j.d.parker@postgrad.curtin.edu.au \\ 2 College of Science, Health, Engineering and Education-Environmental and Conservation Sciences, \\ Murdoch University, Perth WA 6150, Australia \\ * Correspondence: G.Simpson@Murdoch.edu.au
}

Received: 21 October 2018; Accepted: 14 December 2018; Published: 18 December 2018

\begin{abstract}
Consistent with the Land Urbanism and Green Infrastructure theme of this special issue of Land, the primary goal of this review is to provide a plain language overview of recent literature that reports on the psychological, physiological, general well-being, and wider societal benefits that humans receive as a result of experiencing public green infrastructure (PGI) and nature in urbanized landscapes. This enhanced well-being and the wider societal benefits that accrue to urban dwellers as a result of interacting with quality PGI contributes to the concept known as city or urban livability. The quantitative analysis and theoretical synthesis reported in this review can inform decision makers, stakeholders, and other PGI and urban nature (UN) researchers of the benefits that urban populations receive from experiencing quality PGI spaces and UN and the contribution those spaces make to the livability of urban areas. With diminishing opportunities for the acquisition of new public open space to increase PGI and re-establish UN near urban centers, the efficient management and continuous improvement of existing PGI and UN is essential to promote and foster opportunities for human-to-nature contact and the known benefits therein derived. In addition to identifying an increased research interest and publication of articles that report on the contribution of PGI spaces to urban livability over the past decade, the review identifies and reports on the seven focus areas of PGI-livability research and the six attributes of PGI spaces that the current literatures report as contributing to the livability of urbanized landscapes. After providing a quantitative analysis for the reporting of those research areas and PGI attributes and summarizing key findings reported in the literature regarding the contribution that PGI spaces make to urban livability, this review also identifies knowledge gaps in the published literature and puts forward recommendations for further research in this rapidly expanding multidisciplinary field of research and policy development.
\end{abstract}

Keywords: biophilic design; public amenity; public green infrastructure (PGI); public open space; renaturing cities; sustainable development; livability; liveability; urban nature (UN); well-being

\section{Introduction}

First articulated and popularized by Wilson [1], the Biophilic Hypothesis states that humans have an innate, inbuilt affinity to natural systems and living things. Wilson [1] hypothesized that this is likely to be a by-product of evolution, born instinctively from humanity's heritage of hunter-gatherer focused lifestyles. In more recent times, a growing disconnect between humans and nature (extinction of the nature experience) has emerged [2-4]. This disconnection has significant negative impacts on the general health and well-being of increasingly urbanized human populations [2]. Supporting the reconnection of people with urban nature $(\mathrm{UN})$ is critical to reverse the extinction of nature experience 
and to access the wide range of physical and mental health benefits provided by quality public green infrastructure (PGI) that incorporates UN [5].

Numerous authors have reported in detail on the contested definitions and inconsistencies in terminology that prevail in this research space (e.g., [6-12]), so before proceeding further it is important to define the terminology as it is applied in this review. Urban green infrastructure (UGI) is suitably articulated by Norton et al. [13] (p. 128) to be a "network of planned and unplanned green spaces, spanning both the public and private realms, and managed as an integrated system to provide a range of benefits. UGI can include remnant vegetation, parks, private gardens, golf courses, street trees and more engineered options, such as green roofs, green walls, biofilters and raingardens". Within this review article, the term PGI is used for consistency and specifically references vegetated public open spaces and urban public green spaces, such as parks and UN spaces $[10,13,14]$. Urban nature is a UGI element composed of remnant and restored examples of nature indigenous (native) to that locale [14]. Also known as 'indigenous biodiversity', UN spaces should ideally support examples of the micro and macro flora and fauna that would have occupied the area before humans converted the land to an urban matrix. Hereafter, the combination of PGI and UN will be collectively referred to as PGI.

Public green infrastructure affords urban residents with opportunities to exercise, play sports (organized and unorganized), socialize, relax, learn, and experience nature. Aside from the reported psychological and physiological benefits, engaging with PGI has been shown to improve humankind's general outlook on life $[15,16]$. In recent years, global challenges, such as the compelling evidence that climate change is likely to significantly impact the general health and well-being of human populations [16] and evolving social values [17], have driven research into the contribution that PGI makes to urban livability. Researchers also report that provision of PGI can alleviate several other emerging challenges to urban sustainability through the wider social and environmental benefits provided by such spaces (e.g., [16,18-25]). Specifically, these benefits include enhancing environmental management of underutilized or degraded natural assets, increasing conservation of existing PGI assets, micro-climatic advantages, habitat creation for native wildlife, and/or habitat improvement [18-25].

The concept of city/urban 'livability' emerged during the 1980s, as city planners and theorists attempted to describe and quantify how social, political, economic, and environmental factors contributed to the quality of citizen life in urban settlements (e.g., [26-29]). Giap et al. [7] postulated that livability is a place-based concept that encompasses many factors that contribute to the quality of life and well-being of residents. Giap et al. [7] (pp. 178,179) went on to report that the dependence of livability and the quality of the physical environment of a city on "the performance of key urban systems and processes" had spawned several proxy measures for livability that assigned values to those "systems and processes" based on performance, community perception, and other scale dependent factors. The ratings for those factors are consolidated into a single score to be compared against other cities around the world. Currently, two prominent global urban livability scales are produced annually by the United Kingdom based Economist Intelligence Unit (EIU) and the global Mercer LLC consultancy [30]. Both livability scales feature prominently in media reporting and are heavily utilized in promoting the attractiveness of a city as a place to live and visit, which is a valuable tool for influencing decision making processes of individuals, but both have been criticized for not giving sufficient emphasis to PGI spaces in their metrics [26,31]. Another similar scale is the Monocle Quality of Life Survey [32].

Cities with high-ranking livability scores are sought after destinations. Cities that are considered to be highly livable are perceived to provide social and economic benefits, such as foreign business and housing investments; local and international economic stimulus; increased local community involvement and personal connections; and an increase in individuals sense of pride [27,31]. Tzoulas et al. [33] report that quality PGI spaces play an import role by increasing feelings of attachment to their community among urban dwellers and by providing opportunities for them to interact with other residents. 
Public green infrastructure can contribute to urban livability as one of the key urban systems identified by Giap et al. [7] and by providing the social and environmental factors identified by Tzoulas et al. [33]. However, with diminishing opportunities for the acquisition of new public open space to increase PGI and re-establish UN near urban centers, the efficient management and continuous improvement of existing PGI is essential to promote and foster opportunities for human-to-nature contact and the known benefits therein derived. This review provides a quantitative analysis and theoretical synthesis of recent peer-reviewed literature concerning PGI, UN, and the contribution that such spaces make to the livability of urbanized landscapes. Informed by the compilation of the dataset shared via Simpson and Parker [29], we believe this to be the first article to provide a quantitative review of the literature regarding the contribution that PGI makes to urban livability. This systematic review was initially undertaken to inform the design of a questionnaire-based survey that explored the satisfaction of visitors to an urban PGI space [34-36]. The information provided in the Results and Synthesis sections of this review article can, however, inform stakeholders, decision makers, and other researchers regarding the psychological, physiological, and wider societal benefits that urban populations receive from experiencing quality PGI and UN in the context of landscape urbanism and green infrastructure, which is the focus of this special issue of Land.

\section{Methods}

\subsection{Systematic Quantitative Literature Review}

As reported in the Data Descriptor of Simpson and Parker [29], this systematic quantitative literature review is based on the approach of Pickering and Byrne [37] and the Preferred Reporting Items for Systematic Reviews (PRISMA) guidelines (http:/ / prisma-statement.org/) [38].

In December 2016, over 15,000 databases, including Scopus, Web of Science, and all the major English language publishing houses, were searched to identify articles related to PGI, UN, and urban livability using the search terms listed in Table 1. Following the search criteria and PRISMA expression reported in Simpson and Parker [29], two commissioned academic editorial thought pieces, one edited book chapter, and 68 peer-reviewed articles, (hereafter all referred to as 'articles') were identified and deemed suitable for inclusion in this systematic quantitative literature review (Table S1). The PRISMA expression for this systematic review and reported in the Data Descriptor of Simpson and Parker [20] is reproduced here as Figure 1.

As a final measure, a supplementary search using the method detailed above was performed in May 2018 to identify any relevant articles that had become discoverable between January and December 2017. This supplementary search identified another 16 recently published peer-reviewed articles reporting research that was relevant to this review [29]. The 16 articles identified in the supplementary search were analyzed and compared to the 71 articles identified in the initial search.

Table 1. Search terms used to identify papers included in the literature review. Potential papers were filtered using the primary AND secondary search terms.

\begin{tabular}{cc}
\hline Primary Search Terms & Secondary Search Terms \\
\hline "public green infrastructure" & livability/liveability \\
"public open space" & "city livability/liveability" \\
POS & "user satisfaction" \\
"urban open space" & \\
"green space" & \\
"urban nature" & \\
park & \\
wetland & \\
\hline
\end{tabular}

Source: Simpson and Parker [29]. 


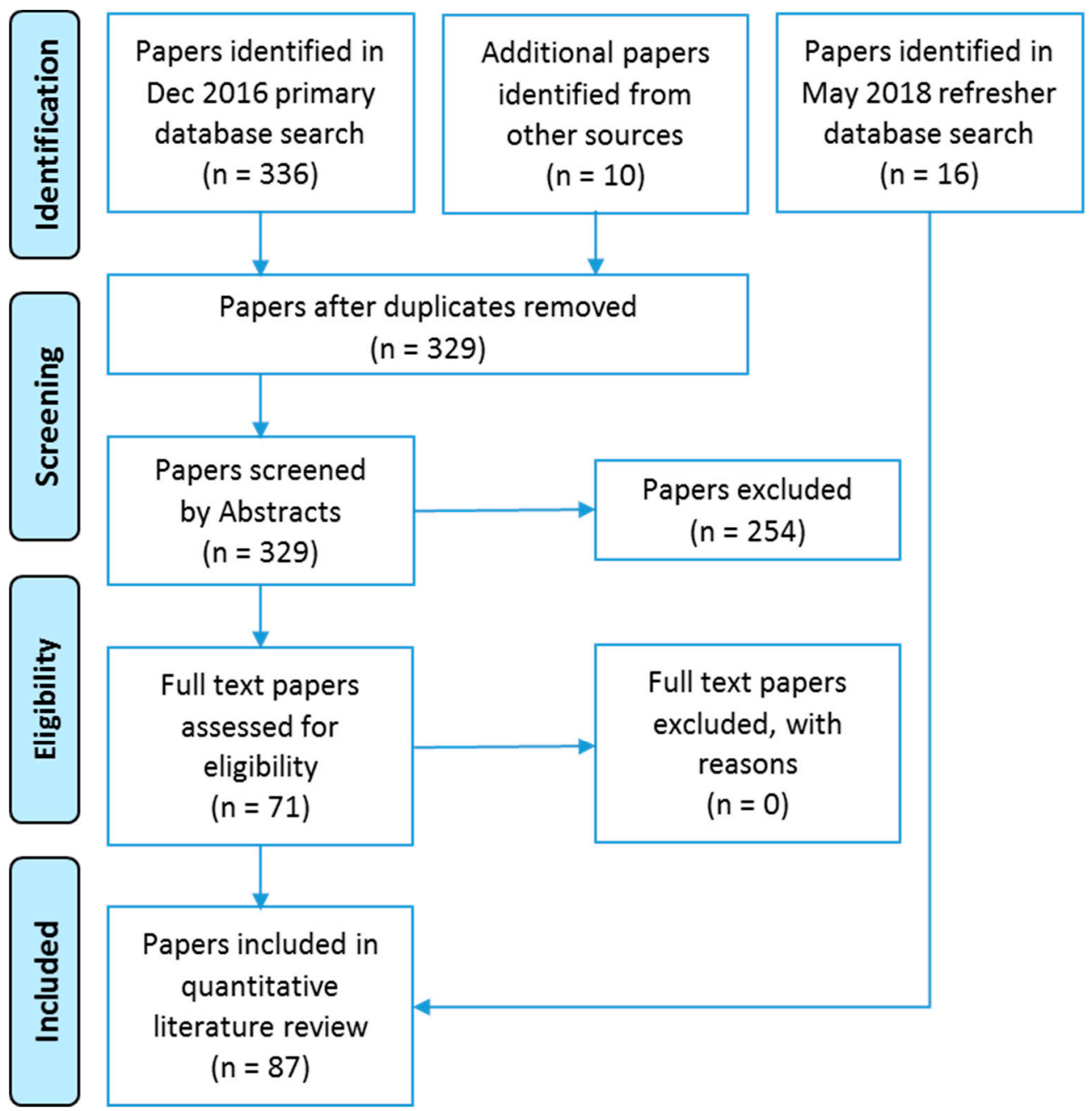

Figure 1. Preferred Reporting Items for Systematic Reviews (PRISMA) Expression for the systematic quantitative literature review. Source: Simpson and Parker [29].

As is standard practice for quantitative reviews, information about the articles are recorded under all/multiple categories for each of the aspects that an article reports against. The full classification of data for each of the articles analyzed under this review is available in the Data Descriptor by Simpson and Parker [29].

\subsection{Data Analyses}

The data analyses provided in this review utilize both graphical and numerical techniques. Figures that report percentages also incorporate error bars that display the $95 \%$ confidence intervals (95\% CIs) for the proportions [39]. For a sample size of $n>10$, if the $95 \%$ CI error bars of two categories overlap for half their length or less, then that provides some evidence for a statistically significant difference $(0.01<\mathrm{p}<\approx 0.05)$ between those parameters [40]. Similarly, if only the tips of the $95 \% \mathrm{CI}$ error bars of two categories overlap, then there is evidence for a statistically significant difference $(\mathrm{p}<\approx 0.01$ ) between those parameters [40]. Comparisons of $95 \%$ CIs across more than two categories can also be informed by a confirmatory statistical test. In this review, the chi-squared $\left(\chi^{2}\right)$ test for goodness of fit was utilized to test the rate of publication in each category against the mean rates of publication across all categories [41] to ascertain if statistically significant patterns could be detected in the rate of reporting with respect to research effort regarding how the attributes of quality PGI spaces contribute to urban livability. Similarly, the chi-squared test for comparison of proportions was utilized to compare between the percentage of articles from the initial search and 
supplementary search reporting a new tool and also the research focus of articles identified in the initial and supplementary searches [41]. Evidence for patterns in the reporting of factors associated with quality PGI spaces and indicators of urban livability (i.e., measures for human health and well-being, for livability, and for social aspects of PGI) was also investigated using the statistically robust Pearson Coefficient of Correlation. Patterns in the publication of PGI attributes identified as contributing to urban livability were also investigated using the Pearson correlation coefficient. Pearson correlation analyses are insensitive to the effects of nonnormality in datasets with $n>5$ and for the type of measurement scale or distribution for $\mathrm{n}>30[42,43]$. These characteristics allow Pearson correlation coefficients to be calculated for the binary data presented in Simpson and Parker [29] in order to investigate linkages in the reporting of the factors associated with quality PGI spaces and the indicators of urban livability $[44,45]$. The significance of all correlations was determined using the similarly robust $t$-test $[46,47]$.

\section{Results}

\subsection{Research Effort}

As previously mentioned in the Methods section, the initial search for this review produced a total of 71 articles on PGI and urban livability deemed appropriate for further analysis, from which several trends were identified. The first trend identified was that the rate of publication suggests an increase in the research effort being directed towards understanding the links between PGI and urban livability (Figure 2). This is especially evident with respect to the past six years where a total of 60 articles were published, representing a $122 \%$ increase on the 27 articles published in the first 12 years of this century.

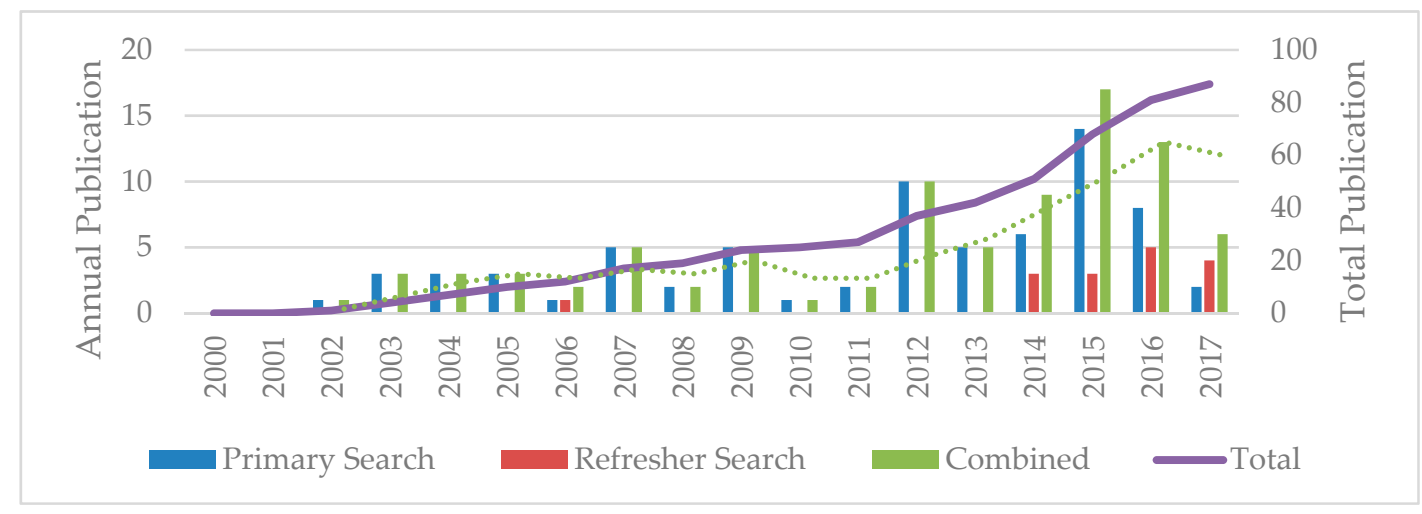

Figure 2. Rate of publication suggests an increase in the research effort being directed towards understanding the links between public green infrastructure (PGI) and urban livability since the year $2000(n=71)$. Green dotted line is the 3-year rolling average for annual publication rate.

\subsection{Geographic Distribution of Research}

Based on the articles identified in the initial review that reported research in relation to specific cities, with 20 published studies Australia dominates research into the connections between urban livability and PGI, both as a country (Figure 3) and a continent (Figure 4). The majority of those studies focused on the Western Australian state capital of Perth, which is one of the two global hotspots for this type of research (Figure 5). The United Kingdom and the United States of America ranked second and third in terms of countries with reported research into links between urban livability and PGI spaces. Interestingly, the developing nations of Indonesia, with studies from the regional capitals of Medan (2 studies) and Semarang (1 studies), and Malaysia, with studies from the national capital of Kuala Lumpur (2 studies) and the Sabahan state capital Kota Kinabalu (1 study), dominate Asian research into the links between urban livability and PGI (Figure 3) and lift Asia ahead of North America for this type of research (Figure 4). As previously mentioned, detailed information about the geographical 
distribution of research into the links between quality PGI and urban livability can be found in the dataset shared via the Data Descriptor of Simpson and Parker [29].

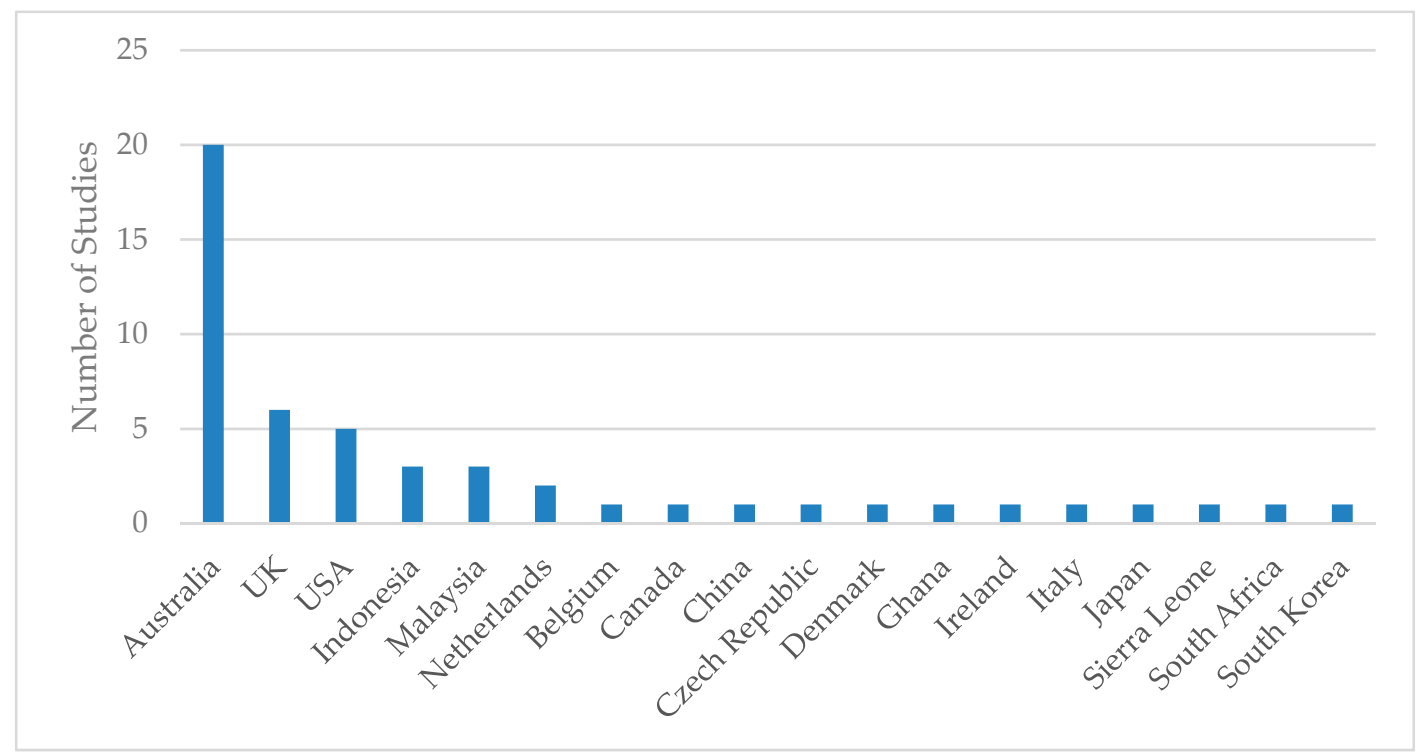

Figure 3. Number of studies that report on linkages between urban livability and PGI spaces for all countries specifically mentioned in the research identified by the initial search. Transnational and international studies reporting on research in multiple countries are recorded against each country.

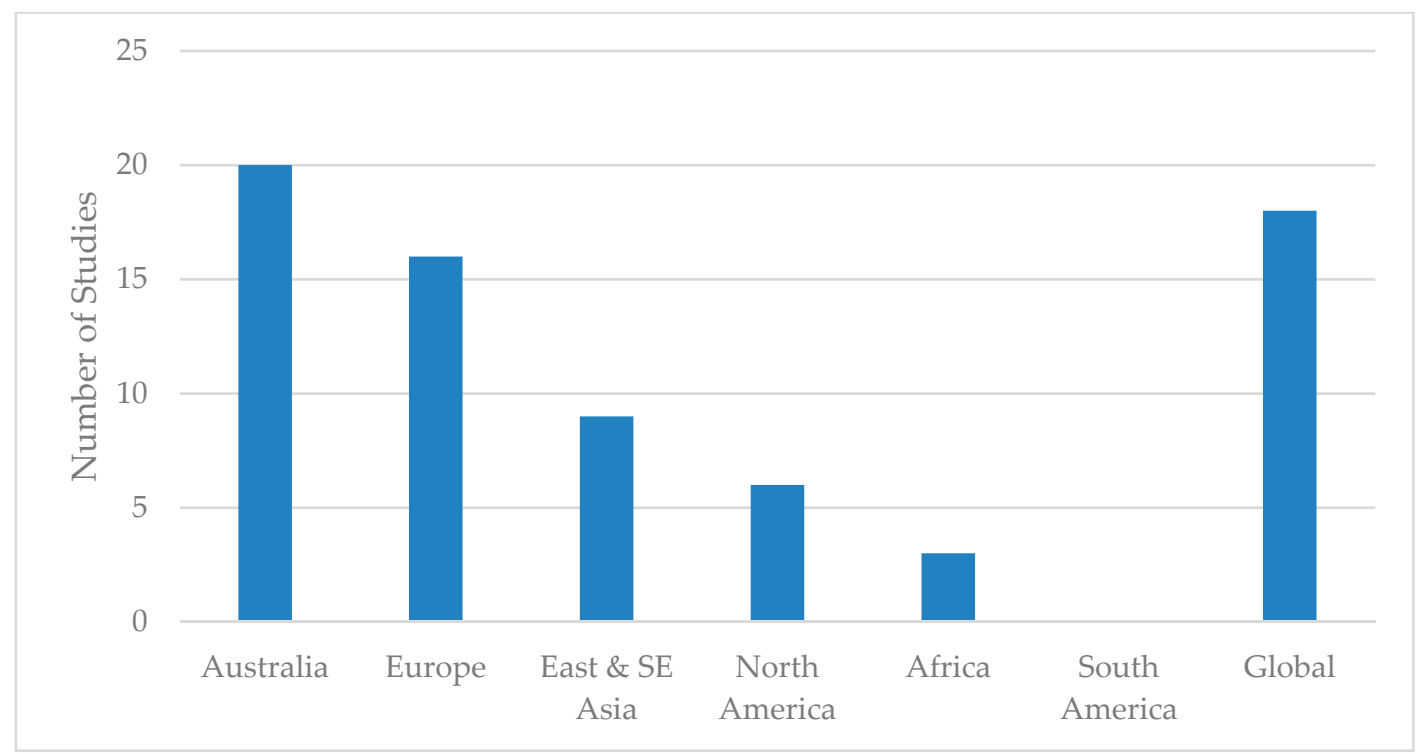

Figure 4. Number of studies that report on linkages between urban livability and PGI spaces by the continent or geographic region identified from the article and the number of globally focused studies (i.e., editorial or review style articles) identified by the initial search. Transnational, international, and continent scale studies are recorded against the relevant continents or geographic regions. 


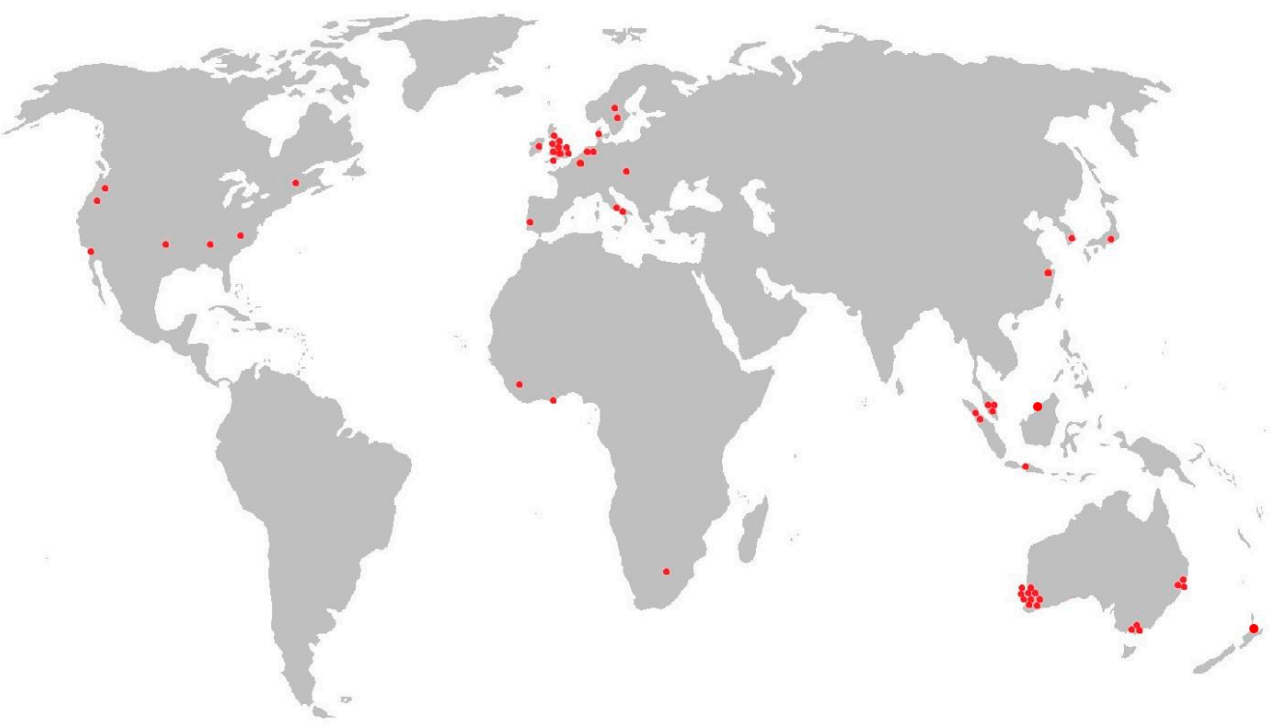

Figure 5. Distribution of research effort into the links between urban livability and PGI identified by the initial search. Markers are placed for all cites specifically mentioned in articles. A marker was not placed for studies where research location was not reported or for articles with a global focus (i.e., editorial or review style articles).

\subsection{Reported Research Methods}

There is a significant difference $\left(\chi^{2}=32.57 ; \mathrm{p}<0.001 ; \mathrm{df}=3\right)$ in the rate of reporting of research approaches (Figure 6). A significant majority (Figure 6) of the articles $(92 \%)$ reported the use of qualitative data collection methods (surveying with open-ended questions, in-depth interviews with participants, observations, and/or focus groups). Slightly fewer articles (73\%) reported the use of quantitative data collection methods (observations/recording of frequencies, surveying with scales or closed questions, and computer-generated data), but the rate for that category was also statistically different. Less than half the articles (42\%) proposed a new tool or method (new PGI quality assessment tools, new data collection methods, or suggested improvements to existing livability and PGI assessment tools) and a similar number of articles (38\%) utilized GIS technology.

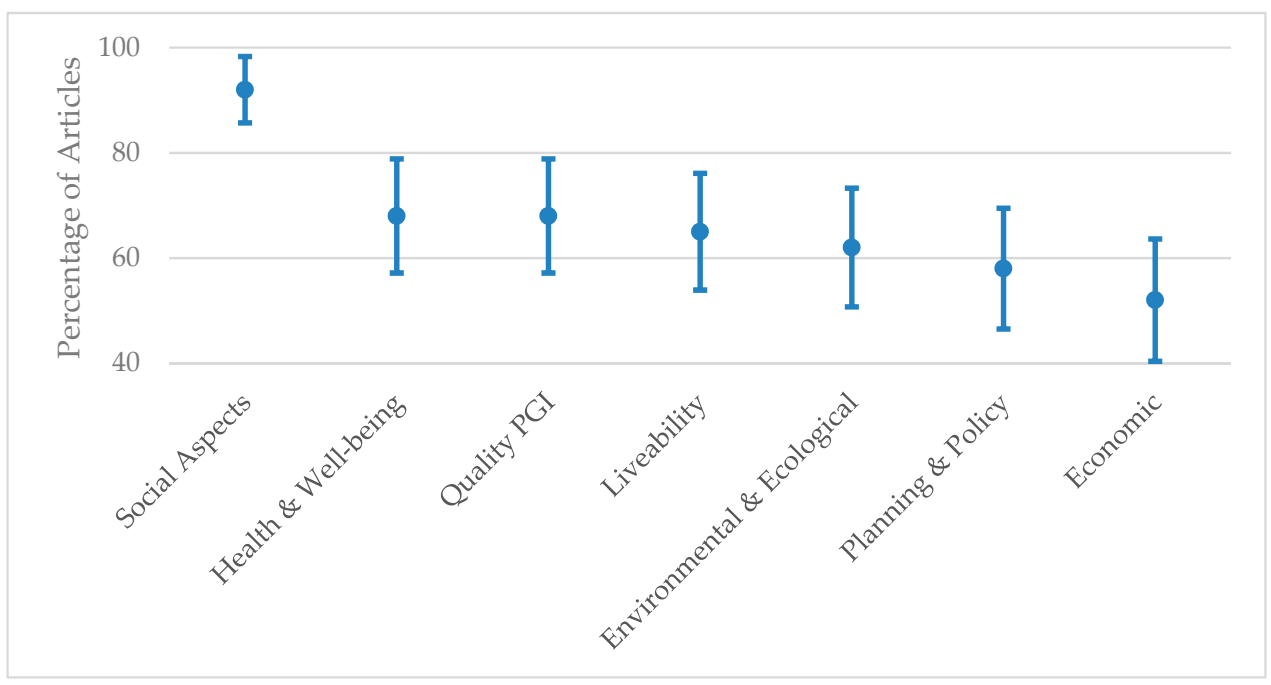

Figure 6. Rate of reporting ( \pm 95\% confidence intervals (CIs) of the proportions) of the four research approaches used to investigate the contribution that PGI makes to urban livability identified by this review $(n=71)$. Percentages add to greater than $100 \%$ because the articles that reported a mixed methods approach to research are reported in multiple categories. 
The research approaches utilized by each of the articles identified in the initial search of this review are shown in Table 2 and a detailed analysis of the research methods utilized under those four approaches is reported in Table 3. Most articles (86\%) reported a mixed methods approach to the research (Table 2).

Table 2. Research approaches utilized, validated, or recommended under each category by study.

\begin{tabular}{|c|c|c|c|c|}
\hline Study & $\begin{array}{c}\text { GIS } \\
(\mathrm{n}=27)\end{array}$ & $\begin{array}{c}\text { Qualitative } \\
(\mathrm{n}=65)\end{array}$ & $\begin{array}{c}\text { Quantitative } \\
(\mathrm{n}=52)\end{array}$ & $\begin{array}{c}\text { PNT } \\
(\mathrm{n}=30)\end{array}$ \\
\hline Antognelli \& Vizzari, [48] & $\checkmark$ & $\checkmark$ & $\checkmark$ & $\checkmark$ \\
\hline Appiah-Opoku [49] & & $\checkmark$ & $\checkmark$ & $\checkmark$ \\
\hline Balding \& Williams [50] & & $\checkmark$ & $\checkmark$ & $\checkmark$ \\
\hline Balram \& Dragićevic [18] & $\checkmark$ & $\checkmark$ & $\checkmark$ & $\checkmark$ \\
\hline Barth et al. [51] & & & $\checkmark$ & \\
\hline Battisti [52] & & $\checkmark$ & & $\checkmark$ \\
\hline Bennett [53] & & $\checkmark$ & & \\
\hline Bratman et al. [19] & & $\checkmark$ & & $\checkmark$ \\
\hline Cattell et al. [20] & & $\checkmark$ & & \\
\hline Čavić \& Beirão [54] & & $\checkmark$ & $\checkmark$ & $\checkmark$ \\
\hline Chen et al. [55] & & $\checkmark$ & $\checkmark$ & \\
\hline Chiesura [56] & & $\checkmark$ & $\checkmark$ & \\
\hline Conteh \& Oktay [15] & & $\checkmark$ & $\checkmark$ & \\
\hline Crawford et al. [57] & $\checkmark$ & $\checkmark$ & $\checkmark$ & \\
\hline Dale \& Connelly [58] & $\checkmark$ & $\checkmark$ & $\checkmark$ & \\
\hline Dallimer et al. [59] & & $\checkmark$ & & \\
\hline de Lange et al. [60] & & $\checkmark$ & $\checkmark$ & \\
\hline De Riddera et al. [61] & $\checkmark$ & & $\checkmark$ & $\checkmark$ \\
\hline Dietsch et al. [62] & & & $\checkmark$ & \\
\hline Do et al. [63] & & $\checkmark$ & $\checkmark$ & \\
\hline Edwards et al. [64] & $\checkmark$ & & $\checkmark$ & $\checkmark$ \\
\hline Francis et al. [65] & $\checkmark$ & $\checkmark$ & $\checkmark$ & \\
\hline Francis et al. [66] & $\checkmark$ & $\checkmark$ & $\checkmark$ & $\checkmark$ \\
\hline Gelissen [67] & & $\checkmark$ & $\checkmark$ & \\
\hline Giap et al. [7] & $\checkmark$ & $\checkmark$ & $\checkmark$ & $\checkmark$ \\
\hline Giles-Corti et al. [68] & $\checkmark$ & $\checkmark$ & $\checkmark$ & $\checkmark$ \\
\hline Grose [21] & $\checkmark$ & $\checkmark$ & $\checkmark$ & $\checkmark$ \\
\hline Hagerman [69] & & $\checkmark$ & & \\
\hline Hartig et al. [70] & & $\checkmark$ & & \\
\hline Hausmann et al. [71] & & $\checkmark$ & & $\checkmark$ \\
\hline Hillsdon et al. [72] & $\checkmark$ & $\checkmark$ & $\checkmark$ & \\
\hline Hock Teck et al. [73] & $\checkmark$ & & $\checkmark$ & \\
\hline Horan et al. [74] & $\checkmark$ & $\checkmark$ & $\checkmark$ & \\
\hline Howley et al. [75] & & $\checkmark$ & $\checkmark$ & \\
\hline Hughes [22] & & $\checkmark$ & & \\
\hline Ikin et al. [76] & & $\checkmark$ & $\checkmark$ & \\
\hline Irvine et al. [77] & & $\checkmark$ & $\checkmark$ & \\
\hline Jones \& Newsome [26] & $\checkmark$ & $\checkmark$ & $\checkmark$ & \\
\hline Kaźmierczak [78] & & $\checkmark$ & $\checkmark$ & \\
\hline Keniger et al. [16] & & $\checkmark$ & $\checkmark$ & \\
\hline Kurniawati [79] & & $\checkmark$ & & $\checkmark$ \\
\hline Malek et al. [80] & & $\checkmark$ & & $\checkmark$ \\
\hline Manfredo et al. [81] & & $\checkmark$ & $\checkmark$ & \\
\hline Massey [82] & & $\checkmark$ & $\checkmark$ & \\
\hline Nasution \& Zahrah [83] & & $\checkmark$ & & \\
\hline Nasution \& Zahrah [23] & & $\checkmark$ & & \\
\hline Newton [27] & & $\checkmark$ & $\checkmark$ & $\checkmark$ \\
\hline Okulicz-Kozaryn [28] & & $\checkmark$ & & $\checkmark$ \\
\hline Revell \& Anda [84] & & $\checkmark$ & & \\
\hline
\end{tabular}


Table 2. Cont.

\begin{tabular}{|c|c|c|c|c|}
\hline Study & $\begin{array}{c}\text { GIS } \\
(n=27)\end{array}$ & $\begin{array}{l}\text { Qualitative } \\
\quad(n=65)\end{array}$ & $\begin{array}{l}\text { Quantitative } \\
\quad(n=52)\end{array}$ & $\begin{array}{c}\text { PNT } \\
(n=30)\end{array}$ \\
\hline Schipperijn et al. [85] & $\checkmark$ & $\checkmark$ & $\checkmark$ & \\
\hline Schneider \& Lorencová [86] & & $\checkmark$ & $\checkmark$ & \\
\hline Shackleton et al. [87] & & $\checkmark$ & $\checkmark$ & \\
\hline Shamsuddin et al. [88] & & $\checkmark$ & & $\checkmark$ \\
\hline Shanahan et al. [89] & $\checkmark$ & $\checkmark$ & $\checkmark$ & $\checkmark$ \\
\hline Shanahan et al. [90] & $\checkmark$ & $\checkmark$ & $\checkmark$ & \\
\hline Simpson \& Newsome [17] & & $\checkmark$ & & \\
\hline Soga et al. [91] & $\checkmark$ & $\checkmark$ & $\checkmark$ & \\
\hline Staats et al. [92] & & $\checkmark$ & $\checkmark$ & \\
\hline Stanley et al. [93] & & $\checkmark$ & $\checkmark$ & $\checkmark$ \\
\hline Sugiyama et al. [94] & $\checkmark$ & $\checkmark$ & & $\checkmark$ \\
\hline Sushinsky et al. [95] & $\checkmark$ & $\checkmark$ & $\checkmark$ & $\checkmark$ \\
\hline Taylor et al. [96] & $\checkmark$ & $\checkmark$ & $\checkmark$ & $\checkmark$ \\
\hline Thompson [12] & $\checkmark$ & $\checkmark$ & $\checkmark$ & $\checkmark$ \\
\hline Tonge \& Moore [97] & & $\checkmark$ & $\checkmark$ & $\checkmark$ \\
\hline Turner et al. [98] & $\checkmark$ & $\checkmark$ & $\checkmark$ & \\
\hline Tzoulas et al. [33] & & $\checkmark$ & $\checkmark$ & $\checkmark$ \\
\hline van den Berg et al. [25] & $\checkmark$ & $\checkmark$ & $\checkmark$ & \\
\hline Van Herzele \& Wiedemann [99] & $\checkmark$ & $\checkmark$ & $\checkmark$ & $\checkmark$ \\
\hline Villanueva et al. [100] & $\checkmark$ & $\checkmark$ & $\checkmark$ & $\checkmark$ \\
\hline Wetzstein [101] & & $\checkmark$ & $\checkmark$ & \\
\hline Zhang [102] & & & & $\checkmark$ \\
\hline
\end{tabular}

Table 3. Research approaches utilized, validated, or recommended under each research category by study (Figure 6).

\begin{tabular}{cccc}
\hline GIS & Qualitative & Quantitative & Proposed New Tool \\
\hline Various spatial & Audit (1 study) & Audit (1 study) & New tool for PGI \\
analyses (28 studies) & Case Study (1 study) & Experiment (1 study) & measurement or \\
& Experiment (1 study) & Focus Group(s) & monitoring (13 studies) \\
& Focus Group(s) & Improvement in \\
& (5 studies) & Interviews (1 study) & understanding of PGI \\
& Interviews (8 studies) & Import.-Performance & attributes or PGI user \\
& Import.-Performance & Analysis (1 study) & behaviors (13 studies) \\
& Analysis (1 study) & Modelling (2 studies) & Improvement to existing \\
& Modelling (1 study) & Observation (17 studies) & livability measurement \\
& Observation (3 studies) & Physical Response & or monitoring tool \\
& Physical Response & (1 study) & Improvement to existing \\
& (1 study) & Review Article & PGI measurement or \\
& Review Article & (15 studies) & monitoring tool \\
& (26 studies) & Survey (13 studies) & (3 studies) \\
\hline
\end{tabular}

GIS = Geographic Information System.

\subsection{Focuses of Urban PGI and Livability Research}

It appears that there was a significantly greater research focus with respect to how the social aspects of PGI spaces, such as a sense of community, social needs, social issues, social services, and the human dimensions contribute to urban livability (Figure 7). There was, however, no overall difference in the rate of reporting for the seven research focus areas relating to the contribution that PGI spaces make to urban livability $\left(x^{2}=10.04 ; p=0.1229 ; \mathrm{df}=6\right)$. In addition to the $92 \%$ of articles identified in the initial search that reported on the contribution of the social aspects of the PGI spaces to urban livability, 
approximately two thirds of the reviewed articles reported research focuses relating to: human health and well-being aspects (68\%); quality of PGI spaces (68\%); the contribution that those spaces make to urban livability (65\%); and the environmental and/or ecological values of those spaces. (62\%). Slightly fewer articles reported on the planning and/or policy aspects of PGI (58\%) and economic benefits of PGI in the urban environment (52\%).

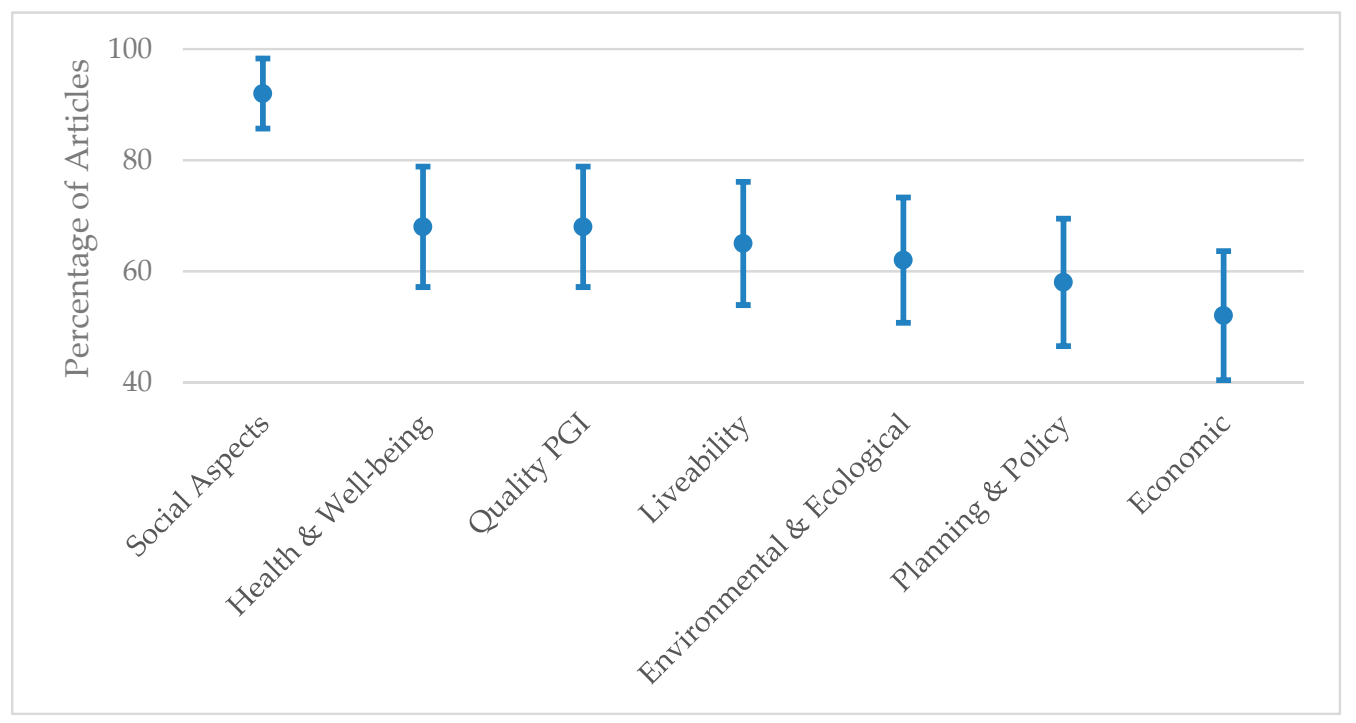

Figure 7. Rate of reporting ( $\pm 95 \%$ confidence intervals (CIs) of the proportions) of the research focus for the contribution that PGI makes to urban livability identified by this review $(n=71)$. Percentages add to greater than $100 \%$ as articles that report multiple focuses are reported in more than one category.

Articles reported between two and seven focus areas for their PGI-livability research (Figure 8). As for the overall research effort, there was no discernible pattern in the number of research focus areas reported in the articles $\left(\chi^{2}=6.584 ; \mathrm{p}=0.2534 ; \mathrm{df}=5\right)$.

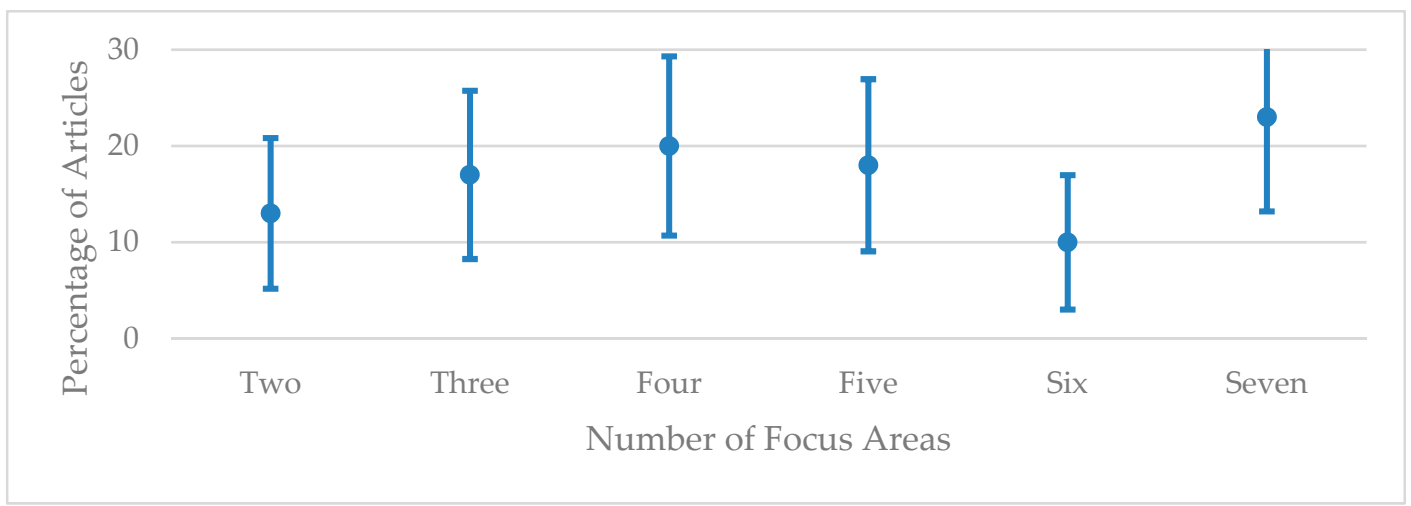

Figure 8. The research focus areas $( \pm 95 \%$ CIs of the proportions) reported by articles identified in the initial search reported by this review $(n=71)$.

Individually collating the research focuses reported in the reviewed articles (Table 4) against the three primary indicators for the contribution of PGI spaces to urban livability (i.e., human health and well-being, livability in its own right, and the social aspects of PGI) also provided no evidence for significant differences in research focus (Figure 9). 
Table 4. Percentage of articles reporting on the research focus for articles identified in the initial search of this reviewer that reported on the contribution that PGI makes to urban livability $(n=71)$. Percentages add to greater than $100 \%$ as articles that report multiple research focus areas are reported in more than one category.

\begin{tabular}{cccccccc}
\hline \multirow{2}{*}{$\begin{array}{c}\text { Primary Indicators of } \\
\text { Livability }\end{array}$} & Health/Wellbeing Livability & $\begin{array}{c}\text { Social } \\
\text { Aspects }\end{array}$ & $\begin{array}{c}\text { Quality } \\
\text { PGI }\end{array}$ & Environ./Ecological & Planning/Policy & Economic \\
\cline { 2 - 8 } & NA & 77 & 90 & 83 & 58 & 63 & 52 \\
Health/Wellbeing Focus & 80 & NA & 93 & 72 & 63 & 74 & 61 \\
Livability Focus & 66 & 66 & NA & 69 & 65 & 62 & 58 \\
Social Aspects Focus & &
\end{tabular}

$\mathrm{NA}=$ Not Applicable as that indicator of livability was the research focus used to cluster the articles.

The high degree of overlap of the 95\% CIs of the proportions, shown in Figure 9, were confirmed by the chi-squared analyses for the rate of reporting research focuses aligned to human health and well-being $\left(\chi^{2}=7.65 ; \mathrm{p}=0.1766 ; \mathrm{df}=5\right)$, aligned to urban livability $\left(\chi^{2}=4.47 ; \mathrm{p}=0.4838 ; \mathrm{df}=5\right)$, and aligned to the social aspects of PGI spaces $\left(\chi^{2}=7.37 ; \mathrm{p}=0.9809 ; \mathrm{df}=5\right)$.

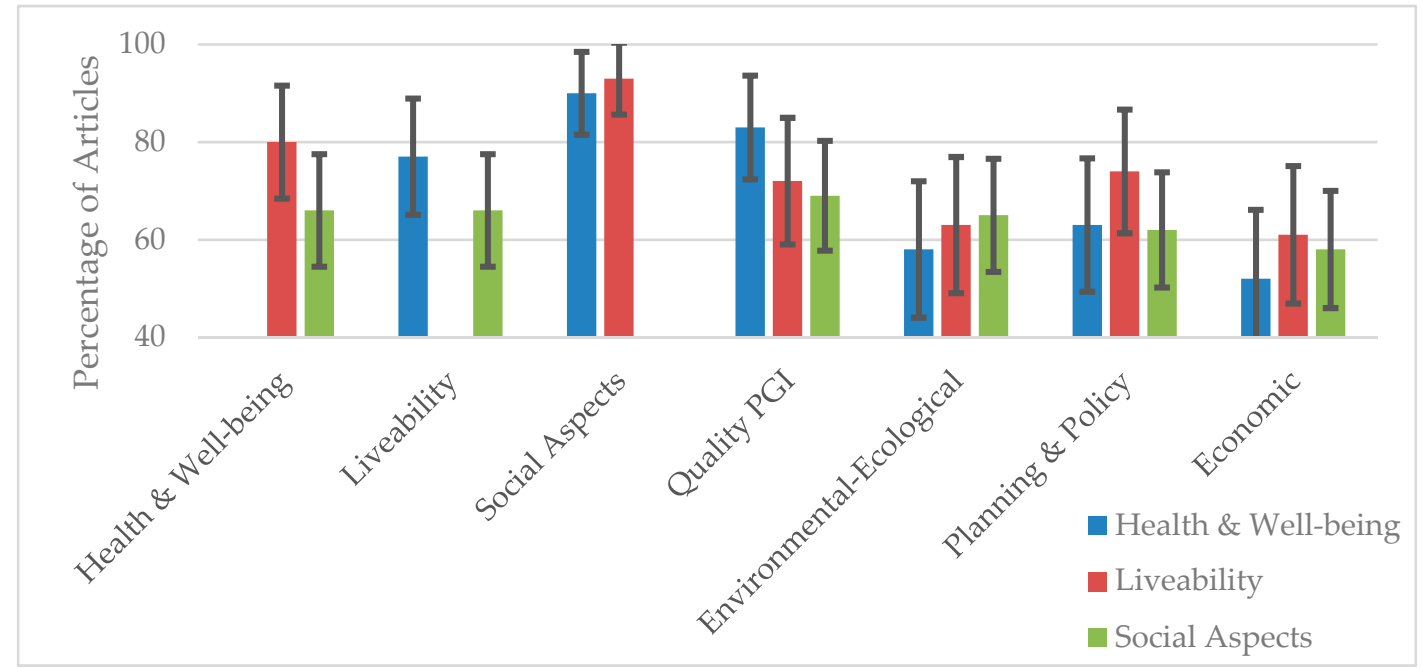

Figure 9. The collated rates of reporting ( $\pm 95 \%$ CIs of the proportions) of research focuses for the contribution that PGI spaces make to urban livability with respect to the key indicators of human health and well-being, livability in its own right, and the social aspects of PGI spaces. Percentages add to greater than $100 \%$ as articles reporting multiple focuses reported in more than one category.

While there is no statistical evidence for any differences in the rate of reporting with respect to livability related factors, nor with respect to the rate of reporting for any particular focus in relation to the three indicators of livability, there is, however, strong evidence of correlations in relation to the reporting of the focuses for research into the contribution that PGI spaces make to urban livability (Table 5). In decreasing order for the strength of the correlation, significant relationships exist with regard to articles identified in the initial search reporting on:

- Human health and wellbeing and the quality of PGI $(\mathrm{r}=0.48 ; \mathrm{p}=<0.0001)$.

- Livability and the planning and policy related to PGI spaces $(r=0.44 ; \mathrm{p}=0.0001)$.

- Human health and wellbeing in conjunction with urban livability $(r=0.37 ; \mathrm{p}=0.0014)$.

- Social aspects of PGI and economic factors $(r=0.32 ; p=0.0071)$.

- Social aspects of PGI and the planning and policy related to PGI spaces $(r=0.25 ; p=0.0335)$.

It is important to exercise caution when drawing inferences for statistical relationships that have p-values close to the level of significance $(\alpha=0.05)$, such cases require informed judgment based on the evidence. The correlation between the reporting of urban livability and economic factors $(r=0.24)$ is comparable to the significant correlation for the social aspects of PGI and the planning and policy 
related to PGI spaces, so the $\mathrm{p}=0.0459$ is likely to be supportive of a significant correlation in the reporting of livability and economic factors. In contrast, the $r=0.08$ correlation between environmental and ecological values of PGI spaces and the quality of PGI spaces suggests that only about $0.5 \%$ of the variability for the reporting of each of those focuses is explained by the reporting of the other. On that basis, the $p$-value associated with that relationship of 0.472 , which rounds to the $\alpha=0.05$ significance level, cannot be considered to provide evidence of a significant correlation.

Table 5. Correlations (lower left) for research focuses reported in articles and p-values for significance of correlations (upper right). Significant correlations and the associated p-value are indicated by an *.

\begin{tabular}{cccccccc}
\hline & Health/Wellbeing Livability & $\begin{array}{c}\text { Social } \\
\text { Aspects }\end{array}$ & $\begin{array}{c}\text { Quality } \\
\text { PGI }\end{array}$ & Environ./Ecological & Planning/Policy & Economic \\
\hline Health/Wellbeing & & 0.0014 & 0.3968 & $<0.0001^{*}$ & 0.3688 & 0.2476 & 0.9944 \\
Livability & $0.37^{*}$ & & 0.4352 & 0.3196 & 0.8042 & $0.0001^{*}$ & 0.0459 \\
Social Aspects & -0.10 & 0.09 & & 0.3426 & 0.1348 & $0.0335^{*}$ & $0.0071^{*}$ \\
Quality PGI & $0.48^{*}$ & 0.12 & 0.11 & & 0.5195 & 0.2476 & 0.6128 \\
Environ./Ecological & -0.10 & 0.03 & 0.18 & 0.08 & & 0.4381 & 0.0472 \\
Planning/Policy & 0.14 & $0.44^{*}$ & $0.25^{*}$ & 0.14 & 0.09 & & $0.0062^{*}$ \\
Economic & $<-0.01$ & 0.24 & $0.32^{*}$ & -0.06 & 0.24 & $0.32^{*}$ & \\
\hline
\end{tabular}

\subsection{Contributors to Urban Livability}

Informed by the research reported in the Data Descriptor of Simpson and Parker [29], research into the linkages between PGI and urban livability identified the six attributes of PGI, shown in Figure 10 and listed in Table 6 as contributing to improved livability of urbanized landscapes. At least one of these factors, and generally more, were reported in 50 of the 71 of the articles (70\%) identified in the initial search. The following analyses relate specially to the 50 articles that reported on the contribution that these PGI attributes make to urban livability.

There was a statistically significant difference $\left(\chi^{2}=24.79 ; \mathrm{p}<0.001 ; \mathrm{df}=5\right)$ with respect to the rate of reporting for these PGI attributes in articles identified in the initial search. The quality of PGI spaces was the most reported attribute (84\%) with respect to its contribution to urban livability. That rate of reporting of that attribute was significantly greater than for the other five attributes. The rate of reporting of the contribution to urban livability arising from the opportunity to experience environmental and ecological processes in the urban landscape $(60 \%)$, the presence of PGI spaces in the urban fabric (48\%), and the ease of access to those PGI spaces $(48 \%)$ were all reported at statistically similar rates, as demonstrated by the overlapping 95\% CIs, shown in Figure 10. Only mentioned in approximately a quarter of the articles that investigated these six PGI attributes, the walkability of PGI spaces $(28 \%)$, and the presence of tree canopy cover $(24 \%)$ were reported at significantly lower rates than the other four attributes.

As for the previously reported focuses of research into the contribution of PGI spaces to urban livability, there were also correlations between the reporting of the six attributes of PGI spaces that this review identifies as contributing to urban livability (Table 6). In decreasing order for the strength of the correlation, the following significant relationships exist with regard to articles identified in the initial search that report on the six attributes of PGI that contribute to urban livability:

- $\quad$ Ease of access to the PGI space and walkability of the PGI space $(r=0.56 ; p=<0.0001)$.

- Walkability of the PGI space and the presence of a tree canopy $(r=0.48 ; \mathrm{p}=0.0004)$.

- Presence of a tree canopy and presence of PGI spaces $(r=0.40 ; p=0.0043)$.

- Presence of a tree canopy and ease of access to the PGI space $(r=0.40 ; p=0.0043)$.

- Presence of PGI spaces and walkability of the PGI space $(r=0.38 ; p=0.0063)$.

- Quality of PGI spaces and ease of access to the PGI space $(r=0.31 ; p=0.0284)$. 


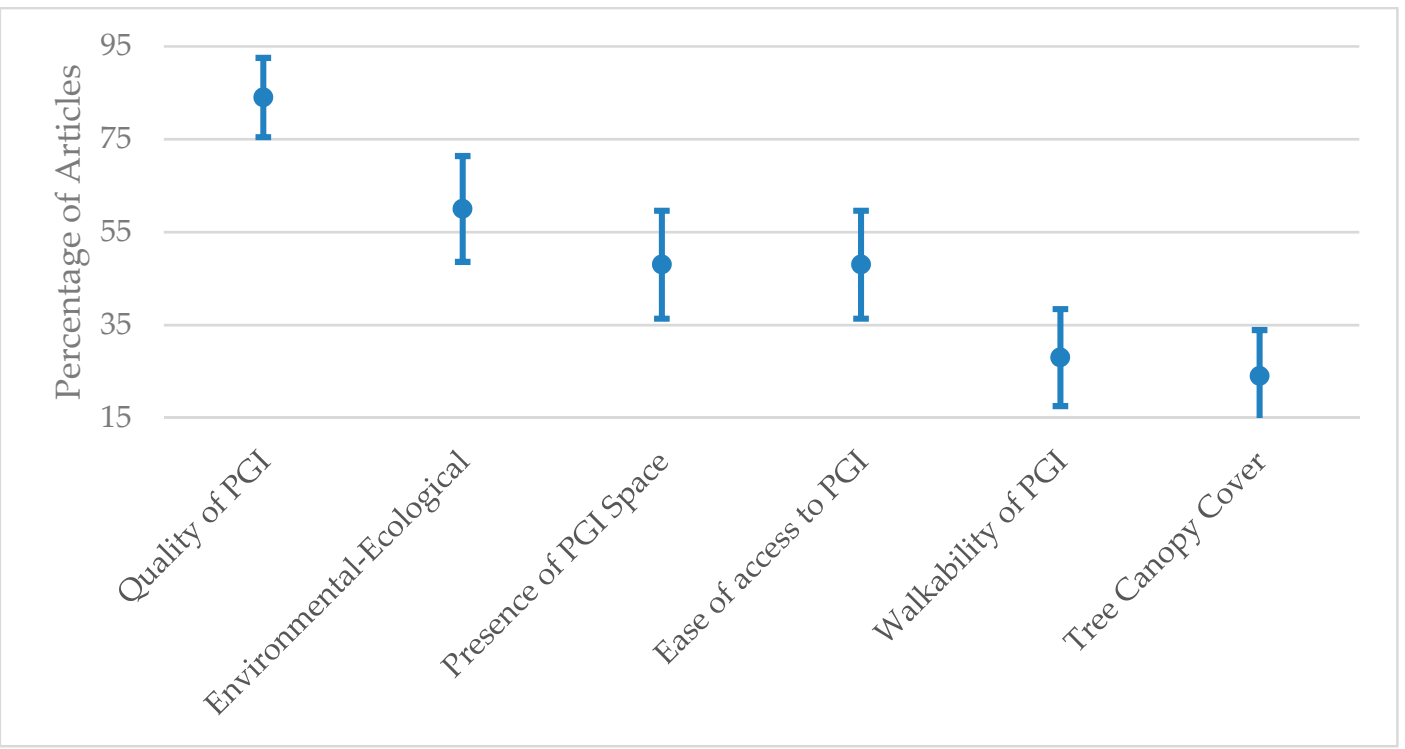

Figure 10. Rate of reporting ( $\pm 95 \%$ CIs of the proportions) regarding the attributes of PGI identified by this review as contributing to urban livability $(n=50)$. Percentages add to greater than $100 \%$ as articles that report multiple attributes are reported in more than one category.

Table 6. Correlations (lower left) between reporting of PGI attributes that contribute to urban livability and the $\mathrm{p}$-values for significance of the correlations (upper right). Significant correlations and the associated $p$-value are indicated by an *.

\begin{tabular}{ccccccc}
\hline & $\begin{array}{c}\text { Quality of } \\
\text { PGI }\end{array}$ & $\begin{array}{c}\text { Enviro. \& } \\
\text { Ecological }\end{array}$ & $\begin{array}{c}\text { Presence of } \\
\text { PGI }\end{array}$ & $\begin{array}{c}\text { Ease of } \\
\text { Access }\end{array}$ & $\begin{array}{c}\text { Walkability } \\
\text { of PGI }\end{array}$ & $\begin{array}{c}\text { Tree } \\
\text { Canopy }\end{array}$ \\
\hline $\begin{array}{c}\text { Quality of PGI } \\
\text { Enviro. \& Ecological }\end{array}$ & -0.13 & 0.3549 & 0.1618 & $0.0284^{*}$ & 0.2963 & 0.4163 \\
Presence of PGI & 0.20 & 0.21 & 0.1385 & 0.8217 & 0.7067 & 0.0602 \\
Ease of Access & $0.31^{*}$ & -0.03 & 0.28 & 0.0499 & $0.0062^{*}$ & $0.0043^{*}$ \\
Walkability of PGI & 0.15 & 0.05 & $0.38^{*}$ & $0.56^{*}$ & $<0.0001^{*}$ & $0.0043^{*}$ \\
Tree Canopy & 0.12 & 0.27 & $0.40^{*}$ & $0.40^{*}$ & $0.48^{*}$ & $0.0004^{*}$ \\
\hline
\end{tabular}

Environ. = Environmental.

The coefficient for the correlation between the reporting of the presence of PGI spaces in urbanized landscapes and ease of access to those PGI spaces is only marginally lower than the correlation between the reporting of the quality of PGI spaces and ease of access to those PGI spaces. The p-value for the significance of that correlation ( $p=0.0499)$, however, rounds to the level of significance $(\alpha=0.05)$, meaning it would be statistically hazardous to draw conclusions about a relationship in the reporting of those two attributes of PGI spaces.

The reporting of these six attributes of PGI spaces that were identified as contributing to urban livability by articles identified in the initial search of this review are shown in Table 7. 
Table 7. Reporting of research into six attributes of PGI spaces that contribute to urban livability.

\begin{tabular}{|c|c|c|c|c|c|c|}
\hline Study & $\begin{array}{c}\text { Quality } \\
\text { of PGI } \\
n=42\end{array}$ & $\begin{array}{c}\text { Enviro. \& } \\
\text { Ecological } \\
\quad \mathbf{n}=30\end{array}$ & $\begin{array}{l}\text { Presence } \\
\text { of PGI } \\
n=24\end{array}$ & $\begin{array}{c}\text { Ease of } \\
\text { Access } n=24\end{array}$ & $\begin{array}{l}\text { Walkability } \\
\text { of PGI n = 14 }\end{array}$ & $\begin{array}{c}\text { Tree Canopy } \\
\mathbf{n}=\mathbf{1 2}\end{array}$ \\
\hline Antognelli \& Vizzari [48] & $\checkmark$ & $\checkmark$ & $\checkmark$ & $\checkmark$ & & \\
\hline Balding \& Williams [50] & & $\checkmark$ & & & & \\
\hline Barth et al. [51] & & $\checkmark$ & & & & \\
\hline Battisti [52] & $\checkmark$ & $\checkmark$ & & & & \\
\hline Cattell et al. [20] & $\checkmark$ & $\checkmark$ & $\checkmark$ & & & \\
\hline Čavić \& Beirão [54] & $\checkmark$ & & & & & \\
\hline Chen et al. [55] & $\checkmark$ & & & & & \\
\hline Chiesura [56] & $\checkmark$ & $\checkmark$ & & & & \\
\hline Dale \& Connelly [58] & $\checkmark$ & $\checkmark$ & $\checkmark$ & & & \\
\hline Dallimer et al. [59] & & $\checkmark$ & & & & \\
\hline De Riddera et al. [61] & & $\checkmark$ & & $\checkmark$ & $\checkmark$ & \\
\hline Dietsch et al. [62] & & $\checkmark$ & & & & \\
\hline Do et al. [63] & $\checkmark$ & $\checkmark$ & & & & \\
\hline Francis et al. [65] & $\checkmark$ & & & & & \\
\hline Francis et al. [66] & $\checkmark$ & & $\checkmark$ & $\checkmark$ & & \\
\hline Giap et al. [7] & $\checkmark$ & $\checkmark$ & $\checkmark$ & $\checkmark$ & $\checkmark$ & $\checkmark$ \\
\hline Giles-Corti et al. [68] & $\checkmark$ & $\checkmark$ & $\checkmark$ & $\checkmark$ & $\checkmark$ & $\checkmark$ \\
\hline Grose [21] & $\checkmark$ & $\checkmark$ & $\checkmark$ & $\checkmark$ & $\checkmark$ & $\checkmark$ \\
\hline Hagerman [69] & $\checkmark$ & $\checkmark$ & & & & \\
\hline Hartig et al. [70] & $\checkmark$ & & & $\checkmark$ & & \\
\hline Hausmann et al. [71] & $\checkmark$ & $\checkmark$ & & & & \\
\hline Howley et al. [75] & $\checkmark$ & & $\checkmark$ & & & \\
\hline Hughes [22] & $\checkmark$ & $\checkmark$ & $\checkmark$ & $\checkmark$ & & $\checkmark$ \\
\hline Irvine et al. [77] & $\checkmark$ & $\checkmark$ & $\checkmark$ & & & \\
\hline Jones \& Newsome [26] & $\checkmark$ & $\checkmark$ & $\checkmark$ & $\checkmark$ & $\checkmark$ & \\
\hline Kaźmierczak [78] & $\checkmark$ & & $\checkmark$ & $\checkmark$ & $\checkmark$ & \\
\hline Keniger et al. [16] & $\checkmark$ & & & & & \\
\hline Kurniawati [79] & $\checkmark$ & & & $\checkmark$ & & \\
\hline Nasution \& Zahrah [83] & $\checkmark$ & & $\checkmark$ & & & \\
\hline Nasution \& Zahrah [23] & $\checkmark$ & & & & & \\
\hline Newton [27] & & & $\checkmark$ & & & \\
\hline Okulicz-Kozaryn [28] & $\checkmark$ & $\checkmark$ & $\checkmark$ & $\checkmark$ & $\checkmark$ & $\checkmark$ \\
\hline Revell \& Anda [84] & & $\checkmark$ & $\checkmark$ & & & \\
\hline Schipperijn et al. [85] & $\checkmark$ & & & $\checkmark$ & & \\
\hline Shackleton et al. [87] & & & & & & $\checkmark$ \\
\hline Shamsuddin et al. [88] & $\checkmark$ & & & & $\checkmark$ & \\
\hline Shanahan et al. [89] & $\checkmark$ & $\checkmark$ & & & & \\
\hline Shanahan et al. [90] & $\checkmark$ & $\checkmark$ & $\checkmark$ & $\checkmark$ & $\checkmark$ & $\checkmark$ \\
\hline Simpson \& Newsome [17] & $\checkmark$ & $\checkmark$ & $\checkmark$ & & & $\checkmark$ \\
\hline Soga et al. [91] & $\checkmark$ & $\checkmark$ & $\checkmark$ & $\checkmark$ & & \\
\hline Sugiyama et al. [94] & $\checkmark$ & & & $\checkmark$ & $\checkmark$ & \\
\hline Sushinsky et al. [95] & $\checkmark$ & $\checkmark$ & & $\checkmark$ & & $\checkmark$ \\
\hline Taylor et al. [96] & $\checkmark$ & & $\checkmark$ & $\checkmark$ & $\checkmark$ & $\checkmark$ \\
\hline Thompson [12] & $\checkmark$ & & & $\checkmark$ & & \\
\hline Turner et al. [98] & $\checkmark$ & $\checkmark$ & & $\checkmark$ & & \\
\hline Tzoulas et al. [33] & $\checkmark$ & $\checkmark$ & $\checkmark$ & & & \\
\hline van den Berg et al. [25] & $\checkmark$ & $\checkmark$ & $\checkmark$ & $\checkmark$ & $\checkmark$ & $\checkmark$ \\
\hline Van Herzele \& Wiedemann [99] & $\checkmark$ & & & $\checkmark$ & & \\
\hline Villanueva et al. [100] & $\checkmark$ & & $\checkmark$ & $\checkmark$ & $\checkmark$ & \\
\hline Zhang [102] & $\checkmark$ & $\checkmark$ & $\checkmark$ & $\checkmark$ & $\checkmark$ & $\checkmark$ \\
\hline
\end{tabular}

Environ. = Environmental. Sourced from Simpson and Parker [29].

\subsection{Future PGI and Urban Livability Research}

Informed by the systematic review reported in the Data Descriptor of Simpson and Parker [29], the initial search revealed that approximately one third (38\%) of articles reported a lack of research with respect to the contribution that PGI spaces make to urban livability. A similar number of articles $(37 \%)$ made recommendations as to the direction that future research should take. Such information is important when determining the current research and knowledge status of the discipline and 
future research that is required to progress understanding of benefits that urban dwellers gain from experiencing PGI spaces, and the linkages between PGI spaces and urban livability. The articles on the contribution of PGI to urban livability were published in 44 journals covering a variety of disciplines (Table 8). This demonstrates the multidisciplinary nature of this emerging field of research and policy, as well as the need to derive learnings from existing research that is grounded across a range of disciplines. Knowledge gaps and research opportunities identified from the literature will be explored further in the following theoretical Synthesis.

Table 8. Name of journals and frequency of reporting for research into the contribution that PGI spaces make to urban livability $(\mathrm{n}=71)$.

\begin{tabular}{|c|c|c|c|}
\hline Name of Journal & Number of Articles & Name of Journal & Number of Articles \\
\hline Landscape and Urban Planning & 12 & Academic Position Paper & 1 \\
\hline Procedia-Social and Behavioral Sciences & 5 & $\begin{array}{l}\text { Acta Universitatis Agriculturae et } \\
\text { Silviculturae Mendelianae Brunensis }\end{array}$ & 1 \\
\hline Conservation Biology & 4 & Ecological Indicators & 1 \\
\hline Journal of Environmental Psychology & 3 & Ecological Management and Restoration & 1 \\
\hline American Journal of Preventive Medicine & 2 & Edited Book & 1 \\
\hline American Journal of Public Health & 2 & Environment and Behavior & 1 \\
\hline Applied Geography & 2 & Environmental Conservation & 1 \\
\hline BioScience & 2 & Frontiers in Ecology and the Environment & 1 \\
\hline Wetlands Ecology and Management & 2 & Geo: Geography and Environment & 1 \\
\hline $\begin{array}{c}\text { World Review of Science, Technology and Sustainable } \\
\text { Development }\end{array}$ & 2 & Global Change Biology & 1 \\
\hline $\begin{array}{l}\text { International Journal of Environmental Research and } \\
\text { Public Health }\end{array}$ & 1 & Public Health & 1 \\
\hline International Journal of the Commons & 1 & Science of the Total Environment & 1 \\
\hline International Journal of Tourism Cities & 1 & Social Indicators Research & 1 \\
\hline Journal of Environmental Planning and Management & 1 & Social Science \& Medicine & 1 \\
\hline Journal of Urban Technology & 1 & Society and Natural Resources & 1 \\
\hline Landscape Ecology & 1 & Sustainability & 1 \\
\hline Local Environment & 1 & Tourism Management & 1 \\
\hline New York Academy of Sciences & 1 & Town Planning Review & 1 \\
\hline Open House International & 1 & & \\
\hline
\end{tabular}

\subsection{Outcomes of Supplementary Search}

The 16 papers collected during the supplementary search, only 18-months after the initial search, revealed a possible change in the focus of PGI-livability research in the period 2014 to December 2017 inclusive (Figure 11). Only one of the articles from the supplementary search reported specifically on livability as a research focus and only two articles focused on the quality of PGI spaces, hence those two research focuses could not be reliably compared to outcomes of the initial search and have been excluded from the following analysis. While the smaller sample size of articles identified in the supplementary search $(\mathrm{n}=16)$ means that care is needed in interpreting possible changes in the focuses for research, using proportions (percentages) for the chi-square analyses and the wider $95 \%$ CIs (Figure 11) compensate for the smaller sample size.

A $2 \times 2$ chi-square analysis provided evidence $\left(\chi^{2}=73.50 ; \mathrm{p}<<<0.001 ; \mathrm{df}=1\right)$ that the apparent reduction in the rate at which articles from the supplementary search (31\%) recommended a new tool could be a significant trend ( $42 \%$ in the initial search).

Similarly, there is statistical evidence $\left(\chi^{2}=15.72 ; \mathrm{p}<<<0.034 ; \mathrm{df}=4\right)$ that the differences in the rates of reporting of research focuses, shown in Figure 11, may also contain significant trends. With the exception of economic factors, the rate of reporting for all other research focuses appears to have declined between the initial and supplementary searches. With no overlap in the $95 \%$ CIs, there is strong evidence for the half as many articles reported research focused on the human health and well-being benefits provided by PGI spaces in the supplementary search $(31 \%)$ compared to the initial search $(68 \%)$ being an evolving trend. The research into the social benefits of PGI demonstrated the smallest decline in reporting (18\%) between the supplementary $(75 \%)$ and initial (92\%) searches. Research into the contribution that the environment and ecological values of PGI spaces make to urban livability appears to have fallen by approximately one third between the supplementary $(44 \%)$ and the initial search $(62 \%)$. There appears to have been a similar one third reduction for research into the links between planning and policy of PGI spaces and livability between the supplementary 
$(38 \%)$ and initial $(58 \%)$ searches. In contrast to the trends for the other research focuses, shown in Figure 11, the reporting of research into the economic factors and the contribution of PGI spaces to urban livability apparently increased by one third between the initial (52\%) and supplementary search $(69 \%)$. These findings are explored further in the Synthesis of this review.

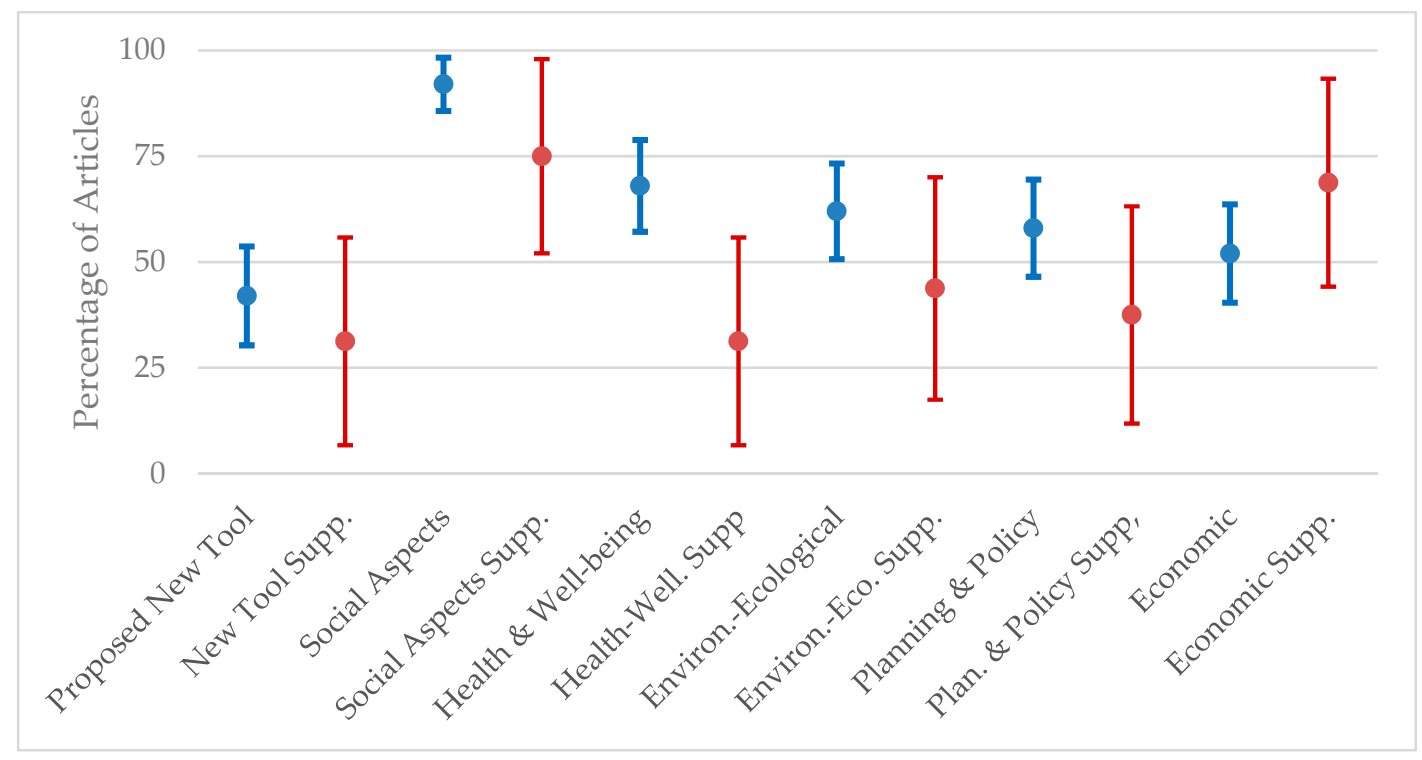

Figure 11. Comparison of changes in reporting rates ( $\pm 95 \%$ CIs of proportions) for research focuses identified in initial (Blue Data) and supplementary (Dark Red) searches. Supp. = Supplementary, Well. $=$ Well-being, Environ. = Environmental, Eco. = Ecological, and Plan. = Planning.

\section{Synthesis}

\subsection{Quantitative Review Summary}

Many PGI researchers report that understanding user experiences, expectations, and satisfaction levels whilst visiting a PGI space is of great value to land managers (e.g., [34,103-107]). Meeting user needs and desires (physical, psychological, and spiritual), as well as providing abundant social, economic, and environmental opportunities, is a primary purpose of urban PGI [103]. Creating and enhancing the synergy between PGI users and land managers is necessary to improve the focus and implementation of management actions and justify the allocation of resources. The primary goal of this review was to provide a plain language overview of recent literature that reports on the psychological, physiological, general well-being, and wider societal benefits that humans receive as a result of experiencing quality PGI spaces in urbanized landscapes and how those PGI spaces contribute to urban livability to improve the quality of life experienced by urban dwellers. The key findings of the quantitative systemic review can be summarized as follows.

Research interest in the benefits that accrue from urban PGI spaces and their contribution to urban livability is growing rapidly with the past six years spawning a $122 \%$ increase in published research compared to the first twelve years of this century (Figure 2). While the majority of that research was centered on mid-latitude cities located in the developed nations of Australia, Europe, and North America (Figure 4), research from Indonesia and Malaysia is also making a significant contribution to understanding how PGI spaces contribute to urban livability. The two global hotspots for this research are the southeast of the United Kingdom and Perth, the geographically isolated state capital located in the southwest of Western Australia (Figure 5).

Approximately four out of ten studies identified in the initial search conducted under this systematic review reported on tools that could be used to assess or quantify the quality of PGI spaces and the contribution those spaces made to urban livability (Figure 6). A similar number of articles analyzed spatial data to explore the characteristics of urban PGI spaces (Figure 6). The majority 
of the research, however, relied on traditional mixed methods research (Tables 2 and 3 ) to gather qualitative and quantitative data about PGI spaces and the people who use and manages those spaces. That research was focused on the seven focus areas (Figure 7) of the social aspects of PGI spaces, the human health and well-being benefits that accrue from visiting PGI spaces, the quality of urban PGI spaces, research focused explicitly on urban livability, the environmental and ecological values of PGI spaces, policy and planning issues associated with urban PGI, and economic factors related to PGI spaces.

The quantitate review reported in the Results section of this article found no statistical evidence of a difference with respect to the rate of reporting of these seven research focus areas, but there were statistically significant correlations between the reporting of some of the research focuses (Table 4). There was a significant correlation for articles that linked the reporting of human health and well-being benefits accruing from visiting PGI spaces and research into the quality of PGI spaces. There was also a correlation between articles reporting on urban livability in combination with research of the planning and policy related to PGI spaces. Given that almost eight out of tenarticles (Figure 9) that mentioned livability also reported on policy and planning, the management framework provided for PGI spaces is an important consideration for urban planners and land managers wishing to optimize the livability of their urban community. The definition of urban livability postulated by Giap et al. [7] and adopted by this review is supported by the positive correlation between the $80 \%$ of articles identified in the initial search that reported on both the human health and well-being benefits that accrue from visiting quality PGI spaces and urban livability. There were also significant correlations between articles that reported on both economic factors and planning and policy related to PGI spaces with articles that reported on the social aspects of the PGI spaces. The reporting for those areas of research were, however, lower than other aspects of PGI-livability research, which means the interpretation of those correlations would require a deeper analysis that was beyond the scope of this review.

This review, informed by the data reported in Simpson and Parker [29], identified six attributes of PGI spaces that are reported by the PGI-livability literature as contributing to improved livability of urbanized landscapes. In order of decreasing frequency of reporting (Figure 10), those attributes are the quality of PGI spaces, the opportunities that PGI space provide to experience the natural environmental and ecological processes (i.e., UN), the presence of PGI spaces in the urban fabric, ease of access to PGI spaces (in terms of both availability and location of PGI spaces and PGI spaces being equitably_socially and physically_accessible all community members), the internal walkability of PGI spaces, and the presence of tree canopy cover at PGI sites.

There was a statistically significant difference in the rate of reporting of these attributes by articles identified in the initial search. Reporting on the contribution of quality of PGI spaces to urban livability was significantly greater than for the other five attributes with slightly better than eight out of every ten articles mentioning that PGI attribute. Only mentioned by approximately one in four articles, the contributions that internal walkability of PGI spaces and the presence of a tree canopy at PGI sites make to urban livability were both reported at a rate significantly below the other four PGI attributes that contribute to urban livability.

There were also significant correlations between the reporting of these attributes, but some those correlations may have a different interpretation of the correlations between the areas of research focus summarized above. The strongest correlation related to reporting of the ease of access to PGI spaces and the walkability of the PGI space. The apparently obvious interpretation of this relationship would be that if PGI spaces are easily accessible, then they would also be highly walkable spaces. Caution needs to be exercised however, as the low reporting of the internal walkability of PGI spaces and the binary nature of the data means it is possible that this correlation is significant because there is an underreporting of PGI walkability (28\% of articles) while almost half of all articles (49\%) reported on the contribution that ease of access to PGI spaces makes to urban livability. It was beyond the primary focus and scope of this review to determine which of those scenarios apply. With similar rates of reporting, it is likely that the presence of tree canopy cover does influence the internal walkability of 
PGI spaces and that the contribution that the combination of those attributes makes to city livability means they are commonly reported together in the PGI-livability literature. Intuitively, the correlation between articles reporting on the presence of a tree cover canopy and the presence of PGI spaces in urban landscapes appears self-evident and a statistical relationship between the reporting of those two attributes would appear to have real-world meaning. Once again however, the disparity in the rate of reporting between the presence of a tree canopy (24\%) and the presence of PGI spaces (48\%), means this correlation could also reflect a significant underreporting of the contribution that a tree canopy makes to urban livability. An interpretation of the correlation between the reporting on the presence of a tree cover canopy at PGI spaces and the ease of access to PGI spaces is not immediately apparent, and similar to the correlation between reporting of the ease of access to PGI spaces and the walkability of the PGI space, further investigation of the literature needs to understand the relationship between the reporting of these attributes. As for the other correlations to reporting of the PGI walkability attribute, the correlation with reporting on the presence of PGI spaces (48\%) could also reflect the under reporting of walkability $(28 \%)$ in the PGI-livability literature. Similarly, the contribution that quality of PGI spaces make to urban livability is reported in significantly more articles than the ease of access to PGI spaces ( $84 \%$ compared to $48 \%$ ), so further investigation, which was beyond the scope of this review, would be needed to interpret the real-world significance of the correlation between the reporting of those two PGI attributes.

It was noted during the quantitative analysis that articles from the supplementary search appeared more focused in their research and reported on fewer research topics than the articles obtained in the initial search, which may have contributed to lower levels of reporting of both new tools for assessing the contribution of PGI spaces to urban livability and the benefits to human health and well-being that accrue from visiting PGI spaces. To increase confidence that these apparent differences between the initial and supplementary searchers are true trends, further monitoring of the literature will be required to complement the small number of new articles identified in the supplementary search.

\subsection{PGI and Livability}

Living in highly urbanized environments often results in diminished opportunities to experience nature. Researchers, such as Soga et al. [91], advocate for the need to increase the value placed on quality PGI spaces, particularly in highly urbanized areas, to reduce the disengagement of people with the surrounding natural world.

A system of quality PGI that supports indigenous ecosystems and sustainable ecological processes is a key determinant for the livability of urbanized landscapes [7]. As demonstrated in the Results section and summarized above, investigating the contribution that the environmental and ecological values of UN make to urban livability has been a key focus for researchers. With environmental and ecological values demonstrated to be a key contributor to improving the livability of urbanised landscapes, urban planners and managers should work to protect conserve, and renaturing PGI spaces for the betterment of their communities and cities more broadly.

When exposed to UN in a quality PGI space, humans experience a greater sense of well-being with psychological, physiological, and biological factors all contributing [16,18-25]. As reported by Giap et al. [7] and reinforced by this review, human well-being is a primary indicator for levels of urban livability. During this time when humans are highly connected via rapidly progressing technology and experiencing highly demanding and competitive working environments, capitalizing on opportunities to engage with the natural environment for psychological benefit has enormous potential for improving social health and well-being outcomes [108], thus making urbanized landscapes more livable. Engaging with elements of the natural environment allows individuals to connect deeply within ourselves, with others, to experience wonder, and to be organically inspired; all representing a marked psychological change for the better [108].

As was highlighted in the Introduction, research into physiological benefits for individuals who engage with the natural environment is also an area of rapid progression. An increase in physical 
activity, improved physical fitness, improved cardiovascular health, and an improvement in children's agility and spatial negotiation skills are just some of the documented benefits $[16,23,109]$. Researchers, such as Gladwell et al. [110] and Li et al. [111], advocate that exposure to nature and nature experiences sees a reduction in stress, improvements in mood, assists in restoring mental fatigue, and enhances the perception of our own physiological health. Those findings are likely to underpin the strong research focus on human health and well-being, quality of PGI spaces, and contribution to urban livability that arise from humans experiencing environmental and ecological processes in PGI spaces reported in this review. The reports of Gladwell et al. [110] and Li et al. [111] and the findings of our review explain why the presence of quality PGI spaces that contain, and support, UN are essential for optimizing the livability of urbanized landscapes.

In established cities with limited opportunities for the acquisition of new land for PGI, creative thinking needs to be applied if adequate PGI spaces are to be provided to residents. Informal PGI installations, such as pop-up gardens, parklets, roof top gardens, and green walls can provide the physical and psychological well-being markers similarly afforded by the traditional PGI spaces that were the focus of this review [2,112]. Examples of successful alternative PGI installations, in line with the Biophilic Hypothesis, made famous by Wilson [1], include an acclaimed green wall at the Musée du Quai Branly (close to the Eiffel Tower) installed by the well-known botanist Patrick Blanc [2] covering the entire façade of a three-story building. Passersby are observed to stop to admire, gaze, and stand in awe of this spectacle [2]. Another is the rooftop garden of the Ballard branch of the Seattle Public Library, which comprises around eighteen thousand native shrub and grass species, which has proven successful in passive heating and cooling, contributing largely to local biodiversity, and acting as an educational showcase for residents and visitors to the area [2]. With rising populations and intensifying density, creative thinking can assist in achieving a way forward to harness diverse opportunities to provide UGI. In addition, PGI resourcing and design is intrinsically linked to the demographics of a population and city. For example, current trends in Australia are showing that people are choosing to have fewer children, have children later in life, and are living longer, due to medical and technological advancements [112]. The combination of these factors is resulting in a significantly aging population [112]. Pre-empting the needs of an aging population means assessing the accessibility and safety of PGI spaces, providing the required infrastructure to support older visitors, creating and supporting passive spaces, and planning for different levels of mobility [112].

While resource allocation is a circular debate, ongoing and adequate resources are required to meet the needs of human populations living in urbanized landscapes. When determining the quality in quality PGI, the following seven areas are consistently reported in current PGI literature: functionality, fair and equitable access, conservation and environmental education, water sensitive management, meeting social needs, infrastructure, and amenities $[48,68,77,89,100,113]$. The level of performance across these features gives an indication of the overall quality of a PGI space. Examples of high performance among these features include: consistent universal access across the site-including infrastructure (e.g., pathways, picnic tables, and playgrounds); use of water sensitive turf and plants; and a practicable site layout with installations that meet the current needs of PGI users. Each of the seven areas above contributes to the visitor experience of a PGI space. It is generally agreed that these features create a foundation of the visitation experience of a typical urban PGI space $[48,68,77,89,100,113]$.

\subsection{Livability Ranking Scales}

Urban livability rankings and performance may be considered by different countries for a variety of reasons. An example is Auckland, New Zealand, where an Urban Growth Management Strategy strongly linked to, and influenced by, urban livability and quality of life considerations are currently being pursued [103]. Current livability scales can reveal information about the performance (high and low) of critical elements of urban centers, which can inform many aspects of urban design and management, including ongoing debates around resource allocation. Research has now progressed 
into understanding the trade-offs that residents may be willing to make when choosing where to live [103]. It has been found that there may be a willingness to forgo quality public transport options to live farther from the city center on a larger parcel of private land, or similarly a willingness to pay a premium price to live in a more central location. This is known as the tradeoff between suburban and urban lifestyles [103]. Understanding how these tradeoffs affect the perception of quality of life and livability is necessary to assess, interpret, and enhance the efficacy and quality of such livability scales [103]. Research into the amenities available to each lifestyle is a largely under researched area. A better understanding in this area would bring value to decision making processes, provision of services, and qualifying resident values in developed, developing, and less developed nations [103]. Ultimately, a progression in such knowledge would assist in the balanced approach to providing PGI that meets the lifestyle choices and expectations and urban dwellers, and would deliver a range of PGI spaces that are perceived to be high value to residents within a city, helping to achieve a diverse, highly functioning, and quality urban living experience. The quantitative analyses and theoretical synthesis reported in this review and the Importance-Performance Analysis case study presented in Parker and Simpson [35] provide the background information and demonstrate an assessment method that will allow urban planners, land managers, and other stakeholders to assess the quality of PGI spaces in their locale and to make informed decisions that will enhance the contribution that those spaces make to both the livability of their community and the broader urban landscape of their city. Citizens who perceive a city to be highly livable are more likely to engage, experience, and enjoy the benefits that the city can offer $[26,28]$. Understanding the factors that contribute to the perception of urban livability is essential for a true and equitable concept of the city. As previously reported in this review, the key determinants of the contribution that PGI spaces can make to the livability of urban landscapes reported in the literature are the presence of quality PGI spaces, that are easily accessed, highly walkable internally, that have tree canopy cover, and, perhaps most importantly, provide the opportunity to experience and engage with quality environmental and ecological systems (i.e., UN), which is an innate need of humanity.

Certain limitations exist in the current livability scales [114]. The current 'one size fits all' ethos for city planning, which includes the provision of PGI and retention of UN, does not consider the development stages of a city when it is under-developed, developing, or developed [114]. Currently, subjective elements, such as opportunities for nature experiences, environmental education, and opportunities for visiting quality PGI are under-represented in livability scales [26]. This may be due to the poor understanding of these elements, the difficulty in quantifying and assigning a 'score' for PGI, and/or the difficulty in verifying 'performance' of urban PGI and UN spaces. The subjective elements that may contribute to urban livability could include how a city protects fragile ecosystems, responds to climate change, funds environmental education programs, addresses resource recovery and waste minimization, the degree of resource depletion, and the social value placed on leisure time [114]. It is the synthesis of this paper, based on the systematic review and guidance of current literature, that the presence and prevalence of high quality PGI and UN (remnant and renatured) is a strong contributor to an individuals' perception of urban livability.

\subsection{Knowledge Gaps and Future Research}

Informed by this review and the Data Descriptor of Simpson and Parker [29], several research gaps pertaining to the different aspects of PGI spaces, the contributions that PGI spaces make to urban livability, and the contribution of PGI to the general health and well-being of urbanized human populations emerged. The research suggested below is relevant for the disciplinary progression, increased research legitimacy, and better provisioning and servicing of urban PGI spaces. Additional research regarding linkages between PGI and urban livability should be focused on:

1. Measures to achieve greater consistency and consensus with respect to terminology, measurement methods, land management approaches, and policy development related to PGI and urban livability. 
2. Investigating the correlations in the rate of reporting of PGI attributes that contribute to urban livability to determine if there are real-world explanations for the patterns identified in the literature or if the correlations reported in this review arose from the discrepancy in the rate of research and/or reporting with respect to some PGI attributes.

3. Replication of existing research to enhance research integrity, particularly with respect to broadly focused research that will identify quality markers of PGI assets and enhance the contribution that quality PGI spaces make to urban livability.

4. Research to further elucidate why exercising within the natural environment requires lessened exertion when compared to exercising indoors.

5. Enhanced understanding of how PGI assets can increase the resilience of urban centers in a cost effective and socially-centric way.

6. Research regarding how access to quality PGI assets influences the quality of citizen life with respect to the concept of urban livability in developing and less developed nations.

7. Determining what aspects of a local PGI space are important enough to surrounding residents that they are willing to contribute personal resources, such as time (volunteering) and financial donations to enhance the site.

\section{Conclusions}

While the PGI and UN research that underpins this review was intentionally weighted towards green public open spaces, such as parks and nature conservation areas, the current literature points to PGI and UN being valuable assets that make important contributions to urban livability, which enhances the quality of life for urbanized human communities. These PGI and UN assets are valuable because they provide numerous social, environmental, economic, and health benefits to urban dwellers. Community members, land managers, urban planners, PGI and livability researcher, and other stakeholders who wish to optimize the livability of urbanized landscapes, and consequently the quality of life of within their community, should give due regard to the complementary aspects of PGI spaces reported in this review, specifically the social aspects and benefits of quality PGI spaces, the human health and well-being benefits arising from visiting quality PGI spaces, the opportunities that PGI spaces provide for urban residents to fulfill their innate need to experience and engage with authentic UN spaces, the planning and policy frameworks associated with the provision and management of quality PGI spaces, and the economic costs and benefits that accrue from the provision of quality PGI spaces. When making decisions with respect to the provision and management of PGI spaces, stakeholders need to be mindful of the six attributes of PGI spaces that this review identifies as making the greatest contribution to urban livability. Those attributes are the presence and persistence in urbanized landscape of PGI spaces that incorporate UN, the quality of those PGI spaces, easy and equitable access to PGI spaces both in a physical and social sense, the importance of PGI spaces in providing urban dwellers with the opportunity to experience and engage with healthy functioning indigenous ecosystems, the internal walkability (and we suggest universal access) of PGI spaces, and the need for tree canopy cover at PGI sites.

Supplementary Materials: The following are available online at http:/ / www.mdpi.com/2073-445X/7/4/161/s1, Table S1: Resources utilized in this systematic quantitative literature review.

Author Contributions: J.P. and G.S. made equal contributions to this paper and as such are co-first authors.

Funding: This research received no external funding.

Acknowledgments: We thank our colleague David Newsome for his guidance on the Master's research by J.P. and comments on the associated thesis. We also give thanks to the Guest Editor of the Land Urbanism and Green Infrastructure special issue, and two anonymous reviewers whose comments enhanced our article. We would like to give particular thanks to Land Editorial Team for their informative, professional, and timely assistance that facilitated the publication of our article.

Conflicts of Interest: The authors declare no conflict of interest. 


\section{References}

1. Wilson, E.O. Biophilia; Harvard University Press: Cambridge, MA, USA, 1984; ISBN 978-0-6740744-2-2.

2. Beatley, T. Biophilic Cities: Integrating Nature into Urban Design and Planning; Island Press: Washington, DC, USA, 2011; ISBN 978-1-5972671-5-1.

3. Miller, J.R. Biodiversity conservation and the extinction of experience. Trends Ecol. Evol. 2005, 20, 430-434. [CrossRef] [PubMed]

4. Neuman, M. The compact city fallacy. J. Plan. Educ. Res. 2005, 25, 11-26. [CrossRef]

5. Kopecká, M.; Szatmári, D.; Rosina, K. Analysis of urban green spaces based on Sentinel-2A: Case studies from Slovakia. Land 2017, 6, 25. [CrossRef]

6. Cameron, R.W.; Blanuša, T.; Taylor, J.E.; Salisbury, A.; Halstead, A.J.; Henricot, B.; Thompson, K. The domestic garden-Its contribution to urban green infrastructure. Urban For. Urban Green. 2012, 11, 129-137. [CrossRef]

7. Giap, T.K.; Thye, W.W.; Aw, G. A new approach to measuring the liveability of cities: The Global Liveable Cities Index. World Rev. Sci. Technol. Sustain. Dev. 2014, 11, 176-196. [CrossRef]

8. Kondo, M.; Fluehr, J.; McKeon, T.; Branas, C. Urban Green Space and Its Impact on Human Health. Int. J. Environ. Res. Public Health 2018, 15, 445. [CrossRef] [PubMed]

9. Roy, S.; Byrne, J.; Pickering, C. A systematic quantitative review of urban tree benefits, costs, and assessment methods across cities in different climatic zones. Urban For. Urban Green. 2012, 11, 351-363. [CrossRef]

10. Swanwick, C.; Dunnett, N.; Woolley, H. Nature, role and value of green space in towns and cities: An overview. Built Environ. 2003, 29, 94-106. [CrossRef]

11. Taylor, L.; Hochuli, D.F. Defining greenspace: Multiple uses across multiple disciplines. Landsc. Urban Plan. 2017, 158, 25-38. [CrossRef]

12. Thompson, C.W. Urban open space in the 21st century. Landsc. Urban Plan. 2002, 60, 59-72. [CrossRef]

13. Norton, B.A.; Coutts, A.M.; Livesley, S.J.; Harris, R.J.; Hunter, A.M.; Williams, N.S. Planning for cooler cities: A framework to prioritise green infrastructure to mitigate high temperatures in urban landscapes. Landsc. Urban Plan. 2015, 134, 127-138. [CrossRef]

14. Unterweger, P.A.; Schrode, N.; Betz, O. Urban Nature: Perception and Acceptance of Alternative Green Space Management and the Change of Awareness after Provision of Environmental Information: A Chance for Biodiversity Protection. Urban Sci. 2017, 1, 24. [CrossRef]

15. Conteh, F.M.; Oktay, D. Measuring liveability by exploring urban qualities of Kissy Street, Sierra Leone. Open House Int. 2016, 41, 23-30.

16. Keniger, L.E.; Gaston, K.J.; Irvine, K.N.; Fuller, R.A. What are the benefits of interacting with nature? Int. J. Environ. Res. Public Health 2013, 10, 913-935. [CrossRef] [PubMed]

17. Simpson, G.; Newsome, D. Environmental history of an urban wetland: From degraded colonial resource to nature conservation area. Geo Geogr. Environ. 2017, 4, E00030. [CrossRef]

18. Balram, S.; Dragicevic, S. Attitudes toward urban green spaces: Integrating questionnaire survey and collaborituve GIS techniques to improve attitude measurements. Landsc. Urban Plan. 2005, 71, 147-162. [CrossRef]

19. Bratman, G.N.; Hamilton, P.; Daily, G.C. The impacts of nature experience on human cognitive function and mental health. N. Y. Acad. Sci. 2012, 1249, 118-136. [CrossRef] [PubMed]

20. Cattell, V.; Dines, N.; Gesler, W.; Curtis, S. Mingling, observing, and lingering: Everyday public spaces and their implications for well-being and social relations. Health Place 2008, 14, 544-561. [CrossRef]

21. Grose, M.J. Changing relationships in public open space and private open space in suburbs in south-western Australia. Landsc. Urban Plan. 2009, 92, 53-63. [CrossRef]

22. Hughes, M. Researching the links between parklands and health. In Wellness Tourism: A Destination Perspective; Voigt, C., Pforr, C., Eds.; Routledge: Abingdon, UK, 2014; pp. 147-160, ISBN 978-1-1-380820-0-7.

23. Nasution, A.D.; Zahrah, W. Public Open Space and Quality of Life in Medan, Indonesia. Procedia Soc. Behav. Sci. 2014, 168, 219-228. [CrossRef]

24. Patroni, J.; Day, A.; Lee, D.; Chan, J.K.L.; Kerr, D.; Newsome, D.; Simpson, G.D. Looking for evidence that place of residence influenced visitor attitudes to feeding wild dolphins. Tour. Hosp. Manag. 2018, 24, 87-105. [CrossRef]

25. Van den Berg, A.E.; Hartig, T.; Staats, H. Preference for nature in urbanized societies: Stress, restoration, and the pursuit of sustainability. J. Soc. Issues 2007, 63, 79-96. [CrossRef] 
26. Jones, C.; Newsome, D. Perth (Australia) as one of the world's most liveable cities: A perspective on society, sustainability and environment. Int. J. Tour. Cities 2015, 1, 18-35. [CrossRef]

27. Newton, P.W. Liveable and sustainable? Socio-technical challenged for the twenty-first century cities. J. Urban Technol. 2012, 19, 81-102. [CrossRef]

28. Okulicz-Kozaryn, A. City life: Rankings (liveability) versus perceptions (satisfaction). Soc. Indic. Res. 2011, 110, 433-451. [CrossRef]

29. Simpson, G.; Parker, J. Data on Peer Reviewed Papers about Green Infrastructure, Urban Nature, and City Liveability. Data 2018, 3, 51. [CrossRef]

30. Conger, B. SPP Research Paper No. 7-4: On Livability, Liveability and the Limited Utility of Quality-of-Life Rankings. Available online: https:/ / papers.ssrn.com/sol3/papers.cfm?abstract_id=2614678\# (accessed on 24 August 2018).

31. The Value of Rankings and the Meaning of Livability. Available online: http:/ /www.livablecities.org/blog/ value-rankings-and-meaning-livability (accessed on 7 August 2018).

32. Quality of Life Survey: Top 25 Cities. 2018. Available online: https://monocle.com/film/affairs/quality-oflife-survey-top-25-cities-2018/ (accessed on 18 November 2018).

33. Tzoulas, K.; Korpela, K.; Venn, S.; Yli-Pelkonen, V.; Kázmierczak, A.; Niemela, J.; James, P. Promoting ecosystem and human health in urban areas using Green Infrastructure: A literature review. Landsc. Urban Plan. 2007, 81, 167-178. [CrossRef]

34. Parker, J. A Survey of Park User Perception in the Context of Green Space and City Liveability: Lake Claremont, Western Australia. Master's Thesis, Murdoch University, Perth, Australia, 2017. Available online: http:/ / researchrepository.murdoch.edu.au/id/eprint/40856/ (accessed on 8 October 2018).

35. Parker, J.; Simpson, G. Visitor satisfaction with a public green infrastructure and urban nature space in Perth, western Australia. Land 2018, 7, 159-176. [CrossRef]

36. Simpson, G.; Parker, J. Data for an Importance-Performance Analysis (IPA) of a public green infrastructure and urban nature space in Perth, western Australia. Data 2018, 7, 69-78. [CrossRef]

37. Pickering, C.M.; Byrne, J. The benefits of publishing systematic quantitative literature reviews for PhD candidates and other early career researchers. High. Educ. Res. Dev. 2013, 33, 534-548. [CrossRef]

38. Moher, D.; Liberati, A.; Tetzlaff, J.; Altman, D.G. Preferred reporting items for systematic reviews and meta-analyses: The PRISMA statement. PLoS Med. 2009, 6. [CrossRef] [PubMed]

39. Berenson, M.L.; Levine, D.M.; Krehbiel, T.C. Basic Business Statistics: Concepts and Applications: International Edition, 10th ed.; Pearson Prentice Hall: Upper Saddle River, NJ, USA, 2006; p. 273, ISBN 978-0131536869.

40. Cumming, G.; Fidler, F.; Vaux, D.L. Error bars in experimental biology. J. Cell Biol. 2007, 177, 7-11. [CrossRef] [PubMed]

41. Berenson, M.L.; Levine, D.M.; Krehbiel, T.C. Basic Business Statistics: Concepts and Applications: International Edition, 10th ed.; Pearson Prentice Hall: Upper Saddle River, NJ, USA, 2006; pp. 454-474, ISBN 978-0131536869.

42. Bishara, A.J.; Hittner, J.B. Testing the significance of a correlation with nonnormal data: Comparison of Pearson, Spearman, transformation, and resampling approaches. Psychol. Methods 2012, 17, 399-417. [CrossRef] [PubMed]

43. Havlicek, L.L.; Peterson, N.L. Robustness of the Pearson Correlation against Violations of Assumptions. Percept. Motor Skills 1976, 43, 1319-1334. [CrossRef]

44. Rodriguez, G.; Elo, I. Intra-class correlation in random-effects models for binary data. Stata J. 2003, 3, 32-46. [CrossRef]

45. Demirtas, H.; Amatya, A.; Doganay, B. BinNor: An R package for concurrent generation of binary and normal data. Commun. Stat.-Simul. Comput. 2014, 43, 569-579. [CrossRef]

46. Edwards, A.L. Statistical Methods for the Behavioral Sciences; Holt, Rinehart and Winston: New York, NY, USA, 1962; pp. 301-304.

47. Berenson, M.L.; Levine, D.M.; Krehbiel, T.C. Basic Business Statistics: Concepts and Applications: International Edition, 10th ed.; Pearson Prentice Hall: Upper Saddle River, NJ, USA, 2006; pp. 266, 546-547, ISBN 978-0131536869.

48. Antognelli, S.; Vizzari, M. Landscape liveability spatial assessment integrating ecosystem and urban services with their perceived importance by stakeholders. Ecol. Indic. 2017, 72, 703-725. [CrossRef] 
49. Appiah-Opoku, S. Using protected areas as a tool for biodiversity conservation and ecotourism: A case study of Kakum National Park in Ghana. Soc. Nat. Resour. 2011, 24, 500-510. [CrossRef]

50. Balding, M.; Williams, K.J. Plant blindness and the implications for plant conservation. Conserv. Biol. 2016, 30, 1192-1199. [CrossRef]

51. Barth, B.J.; FitzGibbon, S.I.; Wilson, R.S. New urban developments that retain more remnant trees have greater bird diversity. Landsc. Urban Plan. 2015, 136, 122-129. [CrossRef]

52. Battisti, C. Experiential key species for the nature-disconnected generation. Anim. Conserv. 2016, 19 , $485-487$. [CrossRef]

53. Bennett, N.J. Using perceptions as evidence to improve conservation and environmental management. Conserv. Biol. 2016, 30, 582-592. [CrossRef] [PubMed]

54. Čavić, L.; Beirão, J.N. Open Public Space Attributes and Categories-Complexity and Measurability. Arhit. Raziskave 2014, 2, 15-24.

55. Chen, B.; Adimo, O.A.; Bao, Z. Assessment of aesthetic quality and multiple functions of urban green space from the users' perspective: The case of Hangzhou Flower Garden, China. Landsc. Urban Plan. 2009, 93, 76-82. [CrossRef]

56. Chiesura, A. The role of urban parks for the sustainable city. Landsc. Urban Plan. 2004, 68, 129-138. [CrossRef]

57. Crawford, D.; Timperio, A.; Giles-Corti, B.; Ball, K.; Hume, C.; Roberts, R.; Andrianopoulos, N.; Salmon, J. Do features of public open spaces vary according to neighbourhood socio-economic status? Health and Place 2008, 14, 889-893. [CrossRef]

58. Dale, P.E.R.; Connelly, R. Wetlands and human health: An overview. Wetl. Ecol. Manag. 2012, $20,165-171$. [CrossRef]

59. Dallimer, M.; Irvine, K.N.; Skinner, A.M.; Davies, Z.G.; Rouquette, J.R.; Maltby, L.L.; Warren, P.H.; Armsworth, P.R.; Gaston, K.J. Biodiversity and the feel-good factor: Understanding associations between self-reported human well-being and species richness. BioScience 2012, 62, 47-55. [CrossRef]

60. De Lange, E.; Woodhouse, E.; Milner-Gulland, E.J. Approaches used to evaluate the social impacts of protected areas. Conserv. Lett. 2016, 9, 327-333. [CrossRef]

61. De Riddera, K.; Adamecb, V.; Bañuelosc, A.; Brused, M.; Bürgerd, M.; Damsgaarde, O.; Dufekb, J.; Hirschf, J.; Lefebrea, F.; Pérez-Lacorzanac, J.M.; et al. An integrated methodology to assess the benefits of urban green space. Sci. Total Environ. 2004, 334-335, 489-497. [CrossRef]

62. Dietsch, A.M.; Teel, T.L.; Manfredo, M.J. Social values and biodiversity conservation in a dynamic world. Conserv. Biol. 2016, 30, 1212-1221. [CrossRef]

63. Do, Y.; Kim, S.B.; Kim, J.Y.; Joo, G.J. Wetland-based tourism in South Korea: Who, When, and Why. Wetl. Ecol. Manag. 2015, 23, 779-787. [CrossRef]

64. Edwards, N.; Hooper, P.; Trapp, G.S.; Bull, F.; Boruff, B.; Giles-Corti, B. Development of a public open space desktop auditing tool (POSDAT): A remote sensing approach. Appl. Geogr. 2013, 38, 22-30. [CrossRef]

65. Francis, J.; Giles-Corti, B.; Wood, L.; Knuiman, M. Creating sense of community: The role of public space. J. Environ. Psychol. 2012, 32, 401-409. [CrossRef]

66. Francis, J.; Wood, L.J.; Knuiman, M.; Giles-Corti, B. Quality or quantity? Exploring the relationship between Public Open Space attributes and mental health in Perth, Western Australia. Soc. Sci. Med. 2012, 74, 1570-1577. [CrossRef] [PubMed]

67. Gelissen, J. Explaining popular support for environmental protection: A multilevel analysis of 50 nations. Environ. Behav. 2007, 39, 392-415. [CrossRef]

68. Giles-Corti, B.; Broomhall, M.H.; Knuiman, M.; Collins, C.; Douglas, K.; Ng, K.; Lange, A.; Donovan, R.J. Increasing walking: How important is distance to attractiveness, and size of public open space? Am. J. Prev. Med. 2005, 28, 169-176. [CrossRef]

69. Hagerman, C. Shaping neighborhoods and nature: Urban political ecologies of urban waterfront transformations in Portland, Oregon. Cities 2007, 24, 285-297. [CrossRef]

70. Hartig, T.; Evans, G.W.; Jamner, L.D.; Davis, D.S.; Gärling, T. Tracking restoration in natural and urban field settings. J. Environ. Psychol. 2003, 23, 109-123. [CrossRef]

71. Hausmann, A.; Slotow, R.O.B.; Burns, J.K.; Di Minin, E. The ecosystem service of sense of place: Benefits for human well-being and biodiversity conservation. Environ. Conserv. 2016, 43, 117-127. [CrossRef]

72. Hillsdon, M.; Panter, J.; Foster, C.; Jones, A. The relationship between access and quality of urban green space with population physical activity. Public Health 2006, 120, 1127-1132. [CrossRef] [PubMed] 
73. Hock Teck, L.H.; Chin Siong, H.; Ali, H.M.; Tu, F. Do institutions matter in neighbourhood commons governance? A two-stage relationship between diverse property-rights structure and residential public open space (POS) quality: Kota Kinabalu and Penampang, Sabah, Malaysia. Int. J. Commons 2016, 10, $294-333$. [CrossRef]

74. Horan, E.; Craven, J.; Goulding, R. Sustainable urban development and liveability. How can Melbourne retain its title as the world's most liveable city and strive for sustainability at the same time? Eur. J. Sustain. Dev. 2014, 3, 61-70. [CrossRef]

75. Howley, P.; Scott, M.; Redmond, D. Sustainability versus liveability: An investigation of neighbourhood satisfaction. J. Environ. Plan. Manag. 2009, 52, 847-864. [CrossRef]

76. Ikin, K.; Le Roux, D.S.; Rayner, L.; Villaseñor, N.R.; Eyles, K.; Gibbons, P.; Manning, A.D.; Lindenmayer, D.B. Key lessons for achieving biodiversity-sensitive cities and towns. Ecol. Manag. Restor. 2015, 16, 206-214. [CrossRef]

77. Irvine, K.N.; Devine-Wright, P.; Payne, S.R.; Fuller, R.A.; Painter, B.; Gaston, K.J. Green space, soundscape and urban sustainability: An interdisciplinary, empirical study. Local Environ. 2009, 14, 155-172. [CrossRef]

78. Kaźmierczak, A. The contribution of local parks to neighbourhood social ties. Landsc. Urban Plan. 2013, 109, 31-44. [CrossRef]

79. Kurniawati, W. Public space for marginal people. Procedia-Soc. Behav. Sci. 2012, 36, 476-484. [CrossRef]

80. Malek, N.A.; Mariapan, M.; Ab Rahman, N.I.A. Community participation in quality assessment for green open spaces in Malaysia. Procedia-Soc. Behav. Sci. 2015, 168, 219-228. [CrossRef]

81. Manfredo, M.J.; Teel, T.L.; Dietsch, A.M. Implications of human value shift and persistence for biodiversity conservation. Conserv. Biol. 2016, 30, 287-296. [CrossRef]

82. Massey, D. Liveable town and cities: Approaches for planners. Town Plan. Rev. 2005, 76, 1-6. [CrossRef]

83. Nasution, A.D.; Zahrah, W. Public open space privatization and quality of life, case study Merdeka Square Medan. Procedia-Soc. Behav. Sci. 2012, 36, 466-475. [CrossRef]

84. Revell, G.; Anda, M. Sustainable urban biophilia: The case of greenskins for urban density. Sustainability 2014, 6, 5423-5438. [CrossRef]

85. Schipperijn, J.; Ekholmb, O.; Stigsdottera, U.K.; Toftagerb, M.; Bentsena, P.; Kamper-Jørgensenb, F.; Randrupa, T.B. Factors influencing the use of green space: Results from a Danish national representative survey. Landsc. Urban Plan. 2009, 95, 130-137. [CrossRef]

86. Schneider, J.; Lorencová, H. Recreational activities, practices and attitudes of visitors to the protected landscape areas as a basis for resolving conflicts of recreation and nature protection. Acta Univ. Agric. Silvic. Mendel. Brun. 2015, 63, 1555-1564. [CrossRef]

87. Shackleton, S.; Chinyimba, A.; Hebinck, P.; Shackleton, C.; Kaoma, H. Multiple benefits and values of trees in urban landscapes in two towns in northern South Africa. Landsc. Urban Plan. 2015, 136, 76-86. [CrossRef]

88. Shamsuddin, S.; Hassan, N.R.A.; Bilyamin, S.F.I. Walkable environment in increasing the liveability of a city. Procedia-Soc. Behav. Sci. 2012, 50, 167-178. [CrossRef]

89. Shanahan, D.F.; Lin, B.B.; Bush, R.; Gaston, K.J.; Dean, J.H.; Barber, E.; Fuller, R.A. Toward improved public health outcomes from urban nature. Am. J. Public Health 2015, 105, 470-477. [CrossRef]

90. Shanahan, D.F.; Lin, B.B.; Gaston, K.J.; Bush, R.; Fuller, R.A. What is the role of trees and remnant vegetation in attracting people to urban parks? Landsc. Ecol. 2015, 30, 153-165. [CrossRef]

91. Soga, M.; Yamaura, Y.; Aikoh, T.; Shoji, Y.; Kubo, T.; Gaston, K.J. Reducing the extinction of experience: Association between urban form and recreational use of public greenspace. Landsc. Urban Plan. 2015, 143, 69-75. [CrossRef]

92. Staats, H.; Kieviet, A.; Hartig, T. Where to recover from attentional fatigue: An expectancy-value analysis of environmental preference. J. Environ. Psychol. 2003, 23, 147-157. [CrossRef]

93. Stanley, M.C.; Beggs, J.R.; Bassett, I.E.; Burns, B.R.; Dirks, K.N.; Jones, D.N.; Linklater, W.L.; Macinnis-Ng, C.; Simcock, R.; Trowsdale, S.A.; et al. Emerging threats in urban ecosystems: A horizon scanning exercise. Front. Ecol. Environ. 2015, 13, 553-560. [CrossRef]

94. Sugiyama, T.; Gunn, L.D.; Christian, H.; Francis, J.; Foster, S.; Hooper, P.; Owen, N.; Giles-Corti, B. Quality of public open spaces and recreational walking. Am. J. Public Health 2015, 105, 2490-2495. [CrossRef] [PubMed]

95. Sushinsky, J.R.; Rhodes, J.R.; Possingham, H.P.; Gill, T.K.; Fuller, R.A. How should we grow cities to minimize their biodiversity impacts? Global Chang. Biol. 2012, 19, 401-410. [CrossRef] [PubMed] 
96. Taylor, B.T.; Fernando, P.; Bauman, A.E.; Williamson, A.; Craig, J.C.; Redman, S. Measuring the quality of public open space using Google Earth. Am. J. Prev. Med. 2011, 40, 105-112. [CrossRef] [PubMed]

97. Tonge, J.; Moore, S.A. Importance-satisfaction analysis for marine-park hinterlands: A Western Australian case study. Tour. Manag. 2007, 28, 768-776. [CrossRef]

98. Turner, W.R.; Nakamura, T.; Dinetti, M. Global urbanization and the separation of humans from nature. BioScience 2004, 54, 585-590. [CrossRef]

99. Van Herzele, A.; Wiedemann, T. A monitoring tool for the provision of accessible and attractive urban green spaces. Landsc. Urban Plan. 2003, 63, 109-126. [CrossRef]

100. Villanueva, K.; Badland, H.; Hooper, P.; Koohsari, M.J.; Mavoa, S.; Davern, M.; Roberts, R.; Goldfeld, S.; Giles-Corti, B. Developing indicators of public open space to promote health and wellbeing in communities. Appl. Geogr. 2015, 57, 112-119. [CrossRef]

101. Wetzstein, S. Perceptions of Urban Elites on Four Australasian Cities: How Does Perth Compare? Committee for Perth, University of Western Australia: Perth, Australia, 2010; pp. 1-17.

102. Zhang, W. Research on how to Improve the Liveability of City Community. Appl. Mech. Mater. 2012, 174-177, 3503-3506. [CrossRef]

103. Allen, N. Understanding the importance of urban amenities: A case study from Auckland. Buildings 2015, 5, 85-99. [CrossRef]

104. Child, S.T.; McKenzie, T.L.; Arrendondo, E.M.; Elder, J.P.; Martinez, S.M.; Ayala, G.X. Associations between park facilities, user demographics, and physical activity levels at San Diego County parks. J. Park Recreat. Adm. 2014, 2014 32, 68-81.

105. Lin, B.B.; Fuller, R.A.; Bush, R.; Gatson, K.J.; Shanahan, D.F. Opportunity or orientation? Who uses urban parks and why. PLoS ONE 2014, 9. [CrossRef] [PubMed]

106. Johnson, A.J.; Glover, T.D. Understanding urban public space in a leisure context. Leis. Sci. 2013, 35, $190-197$. [CrossRef]

107. Matsuoka, R.H.; Kaplin, R. People needs in the urban landscape: Analysis of landscape and urban planning contributions. Landsc. Urban Plan. 2008, 84, 7-19. [CrossRef]

108. Cracknell, D.; White, M.P.; Pahl, S.; Nichols, W.J.; Depledge, M.H. Marine biota and psychological well-being: A preliminary examination of dose-response effects in an aquarium setting. Environ. Behav. 2016, 48, 1242-1269. [CrossRef] [PubMed]

109. Davern, M.; Farrar, A.; Kendal, D.; Giles-Corti, B. Quality Green Space Supporting Health, Wellbeing and Biodiversity: A Literature Review; National Heart Foundation of Australia: Adelaide, Australia, 2017; pp. 1-39, ISBN 978-0-9872841-7-4.

110. Gladwell, V.F.; Brown, D.K.; Wood, C.; Sandercock, G.R.; Barton, J.L. The great outdoors: How a green exercise environment can benefit all. Extreme Physiol. Med. 2013, 2, 1-7. [CrossRef] [PubMed]

111. Li, Q.T.; Otsuka, M.; Kobayashi, Y.; Wakayama, H.; Inagaki, M.; Katsumata, Y.; Hirata, Y.; Li, Y.; Hirata, K.; Shimizu, T.; et al. Acute effects of walking in forest environments on cardiovascular and metabolic parameters. Eur. J. Appl. Physiol. 2011, 111, 2845-2853. [CrossRef] [PubMed]

112. Rupprecht, C. Informal urban green space: Residents' perception, use, and management preferences across four major Japanese shrinking cities. Land 2017, 6, 59. [CrossRef]

113. Specht, R.L. Vegetation. In The Australian Environment, 4th ed.; Leeper, G.W., Ed.; CSIRO-Melbourne University Press: Melbourne, Australia, 1970; pp. 44-67.

114. Onnom, W.; Tripathi, N.; Nitivattananon, V.; Ninsawat, S. Development of a liveability city index (LCI) using multi criteria geospatial modelling for medium class cities in developing countries. Sustainability 2018, 10, 520-539. [CrossRef]

(C) 2018 by the authors. Licensee MDPI, Basel, Switzerland. This article is an open access article distributed under the terms and conditions of the Creative Commons Attribution (CC BY) license (http:/ / creativecommons.org/licenses/by/4.0/). 